\title{
تبنى مربى الأبقار للتوصيات الإرشادية للوقاية من مرض الجلد العقدى ببعض قرى محافظة الغربية
}

\author{
شادى عبد السلام محمد الطنطاوى، أحمد ممدوح عبد الجليل عامر، \\ ولاء إبراهيم إبراهيم المغازى \\ معهد بحوث الإرشاد الزراعى والتنمية الريفية - مركز البحوث الزراعية
}

Received: Mar. 8 , 2020

Accepted: May` , 2020

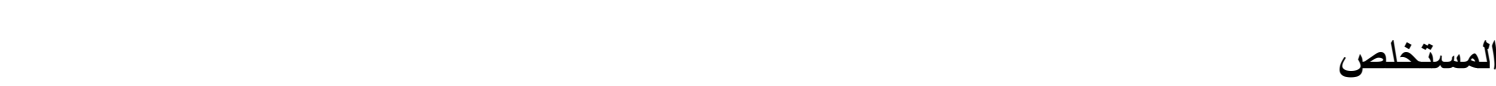

أستهـف هذا البحث التعرف على مستوى تبنى مربى الأبقار المبحوثين للتوصيات الإرشسادية للوقاية من مرض الجلد

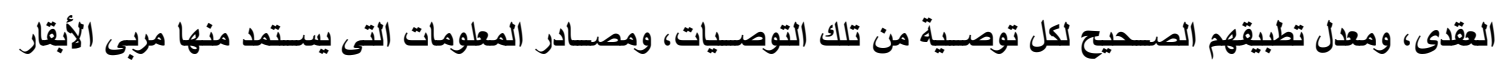

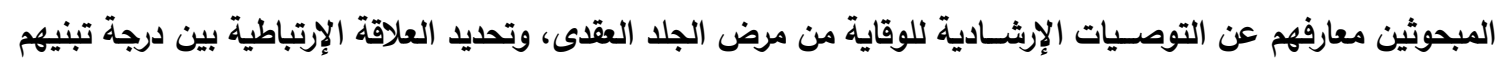

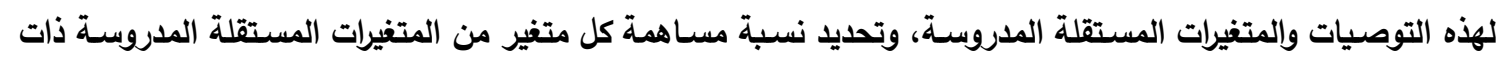

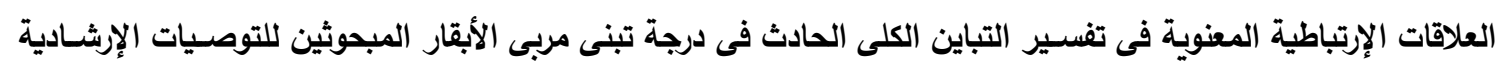

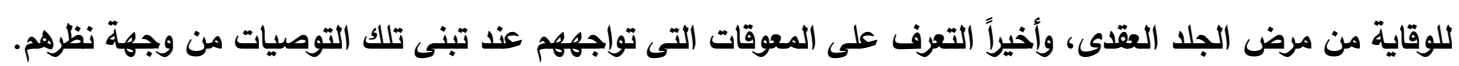

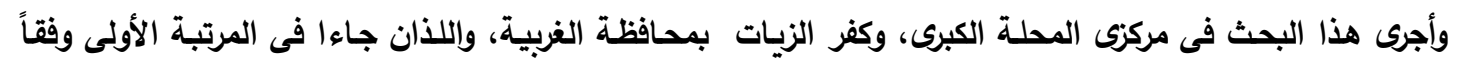

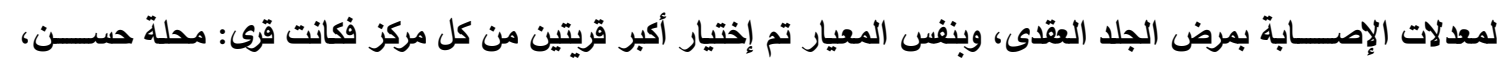

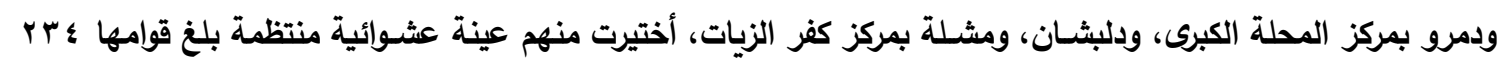

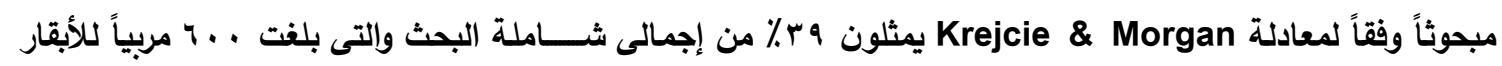

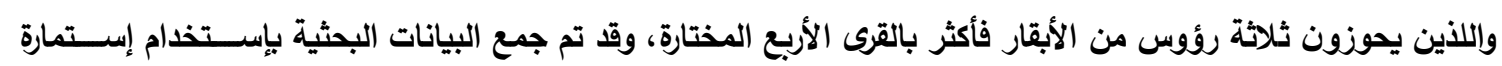

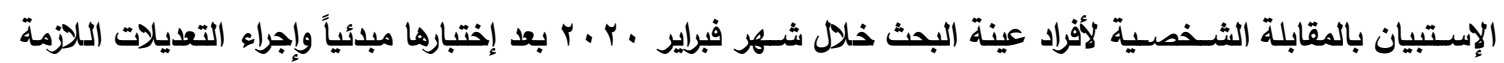

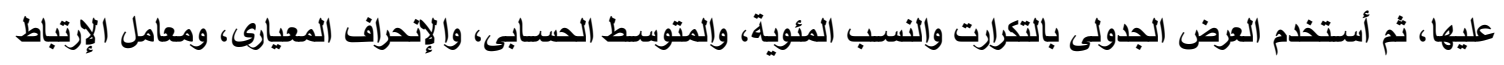

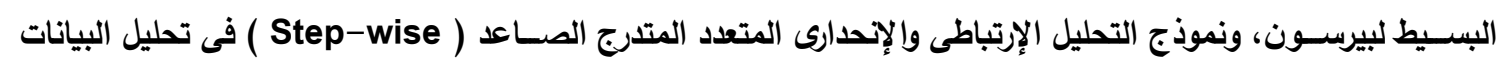
إحصائياً وعرض النتائج.

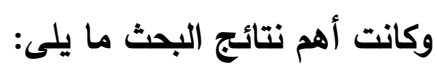
1- أن به \% من مربى الأبقار المبحوثين كان مســتوى تبنيهم منذفضــاً للتوصـيات الإرشــادية للوقاية من مرض الجلد العقدى.

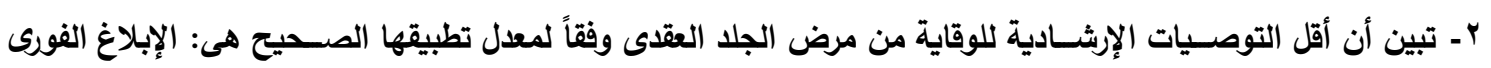

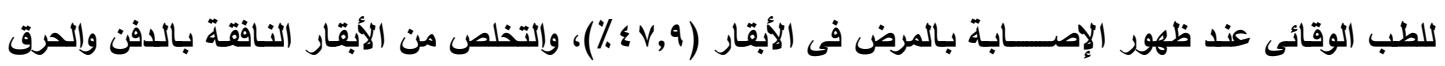

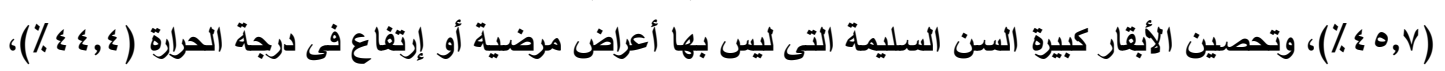

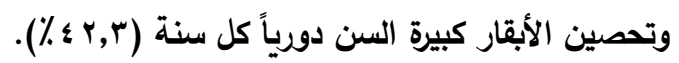

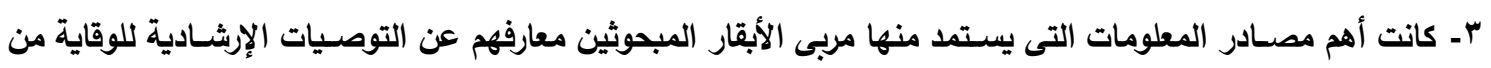

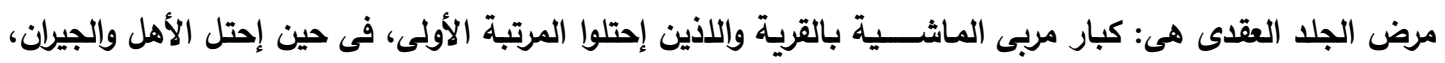
والخبرة الثخصية مراتب متقدمة وتالية لهم. 
ع - وجود سـتة متغيرات مسـتقلة مجتمعة معاً تفسـر نسبة 1,9 ؛ ٪ من التباين الكلى الحادث فى درجة تبنى مربى الأبقار

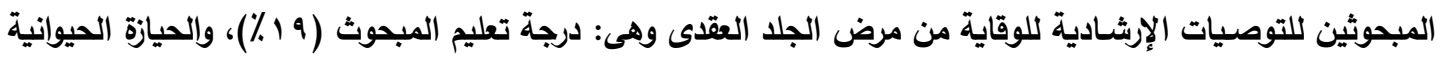

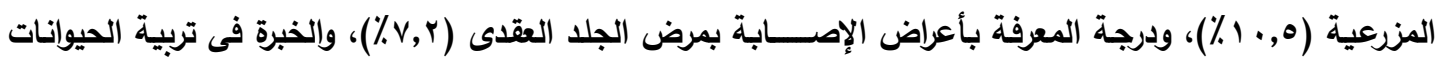

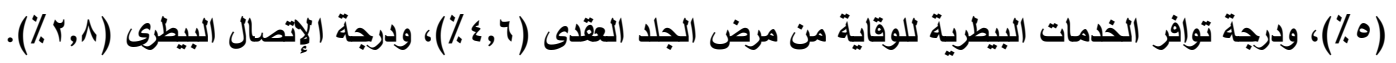

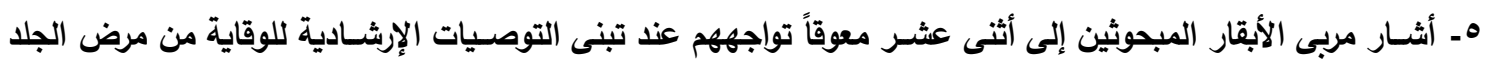

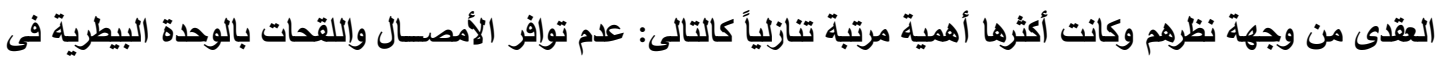

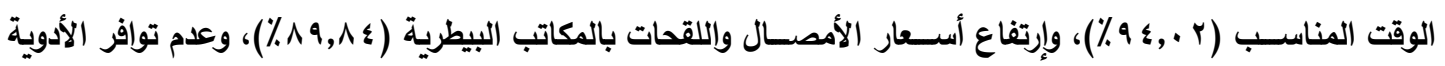

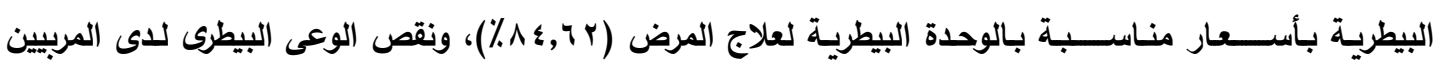

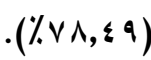

الكلمات الإسترشادية: التبنى - توصيات الوقاية - مرض الجلد العقدى

وبالرغم من ذلك يواجه قطاع الثروة الحيوانية العديد

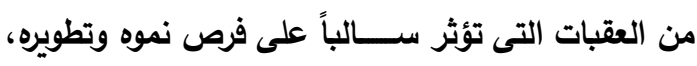

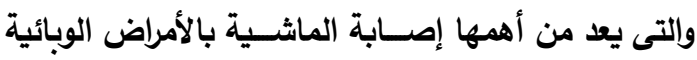

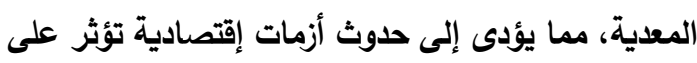

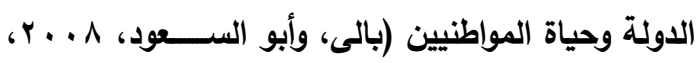

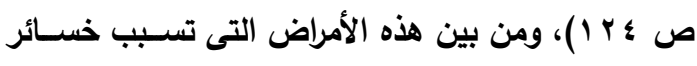

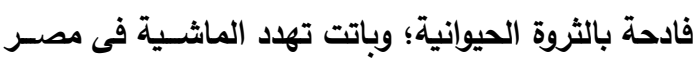

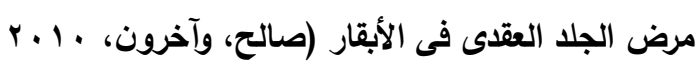

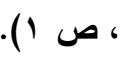

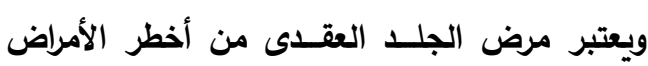

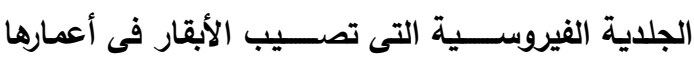

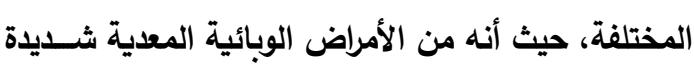

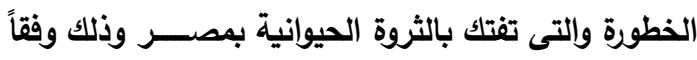

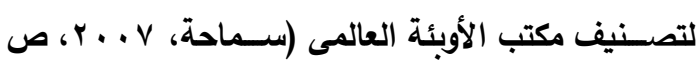
؟)، والأى بلءء ظهوره فى محافظتى السويس والإسماعلية

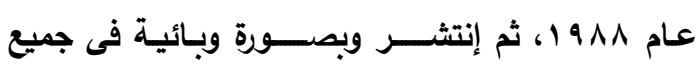

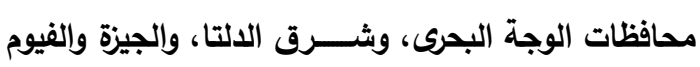

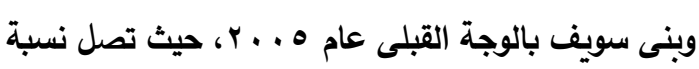

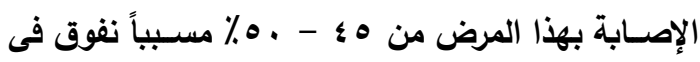

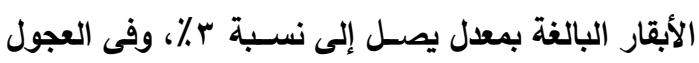

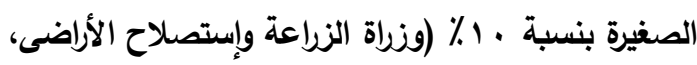

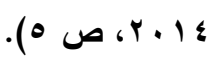

المقدمة والمشكلة البحثية يعد قطاع الثروة الحيوانية من أهم القطاعات التنموية

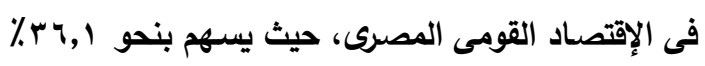

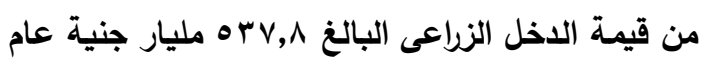

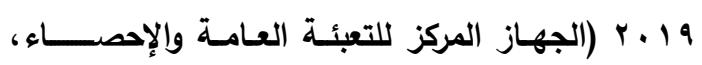

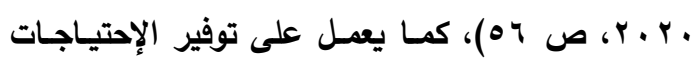
الغذائية للسكان من المنتجات الحيوانية، والتى تعد مصدراً

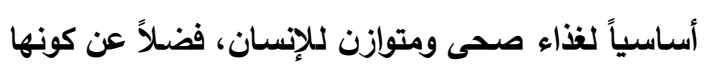

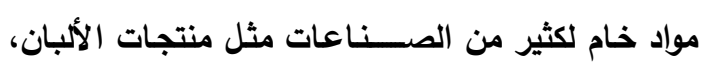

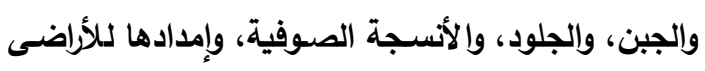

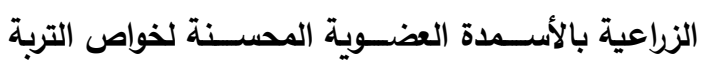

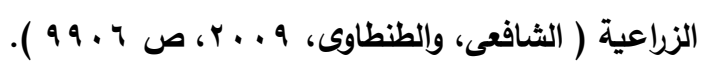
ويمثل قطاع الثروة الحيوانية فى مصر عنصراً أساسياً من عناصر الإتتاج الزراعى، لما يتميز به بتركيزه الثديد

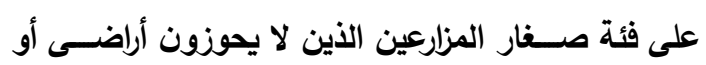

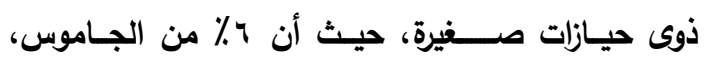

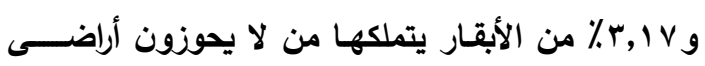

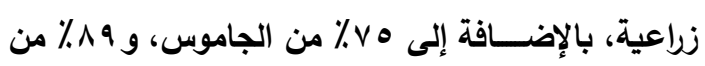

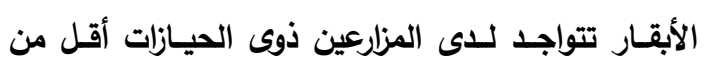

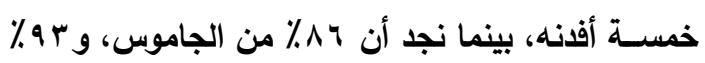
من الأبقار تتواجد فى قطعان أقل من عشرة رؤوس (وزراة

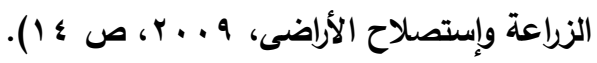




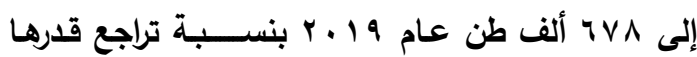

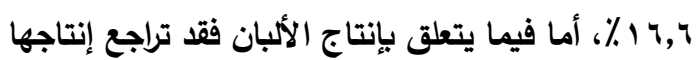

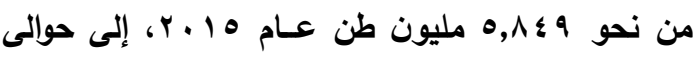

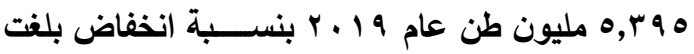

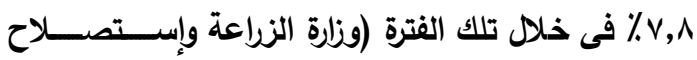

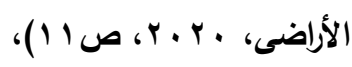

مما يعكس بلا شـــك تدنى نصـــيب الفرد من اللحوم

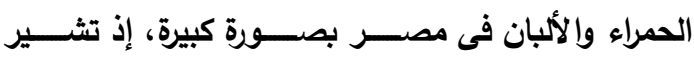

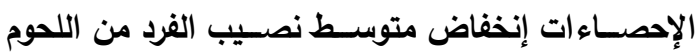

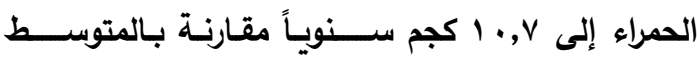

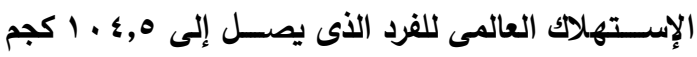

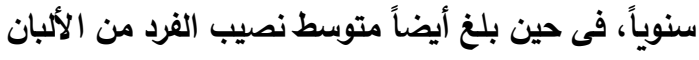

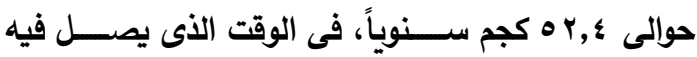

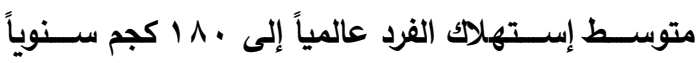

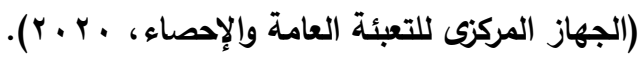
لذا فقد كانت أهم التوجهات المسـتقبلية لتنمية قطاع

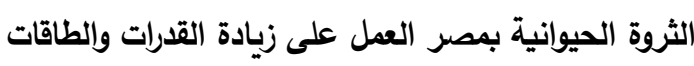
الإنتاجية الحيوانية فى إطار إسـتراتيجية التنمية الزراعية

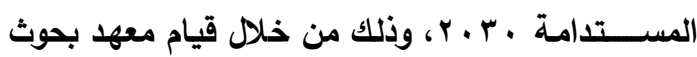

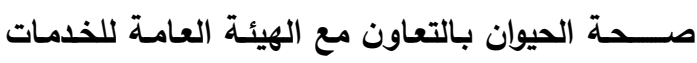
البيطرية ومديريات الطب البيطرى على مستوى الجمهورية

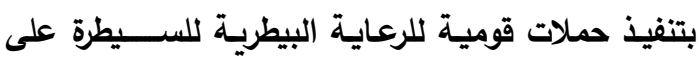

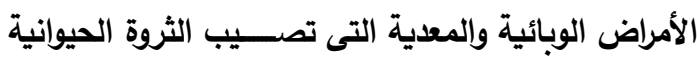

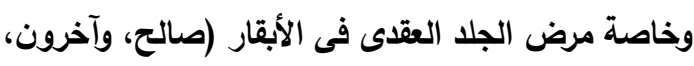

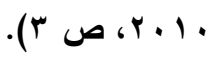

هذا وتعتبر محافظة الغربية من أكثر محافظات الوجه

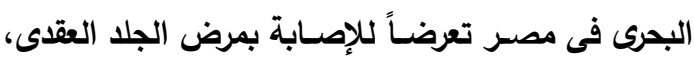

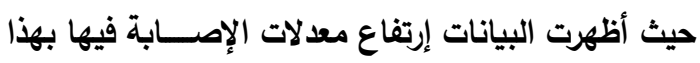

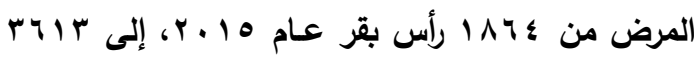

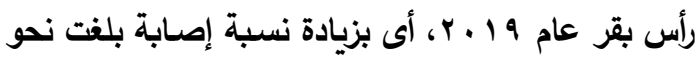

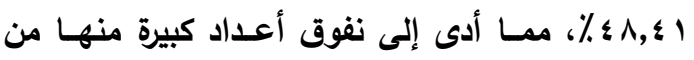

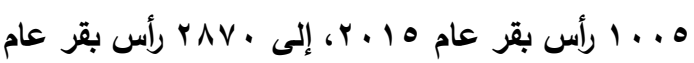

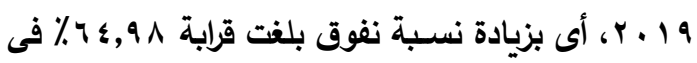

وهو ما أكلته الإحصـاءات حيث أثــارات إلى إرتفاع

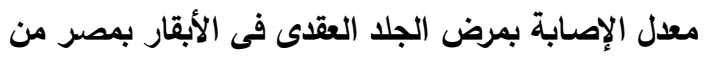

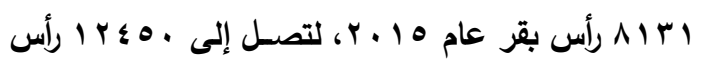

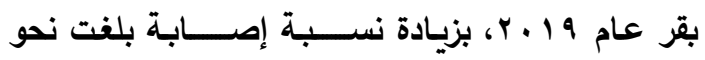

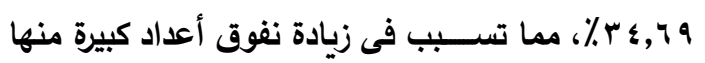

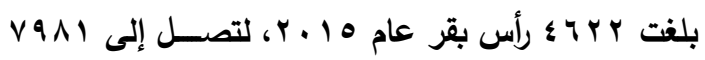

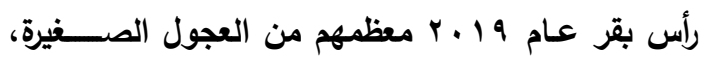

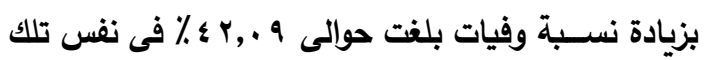

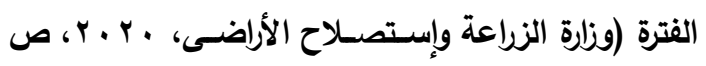

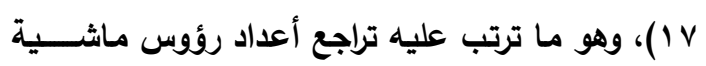

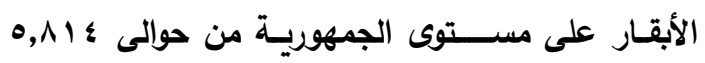

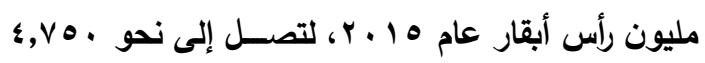

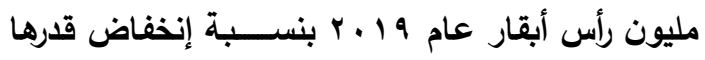

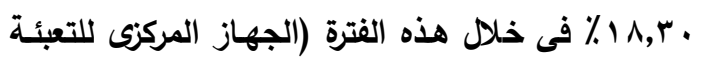

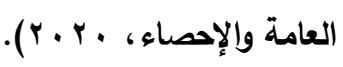
الأمر الذى أدى إلى حدوث خسـائر إقتصـادية فادحة

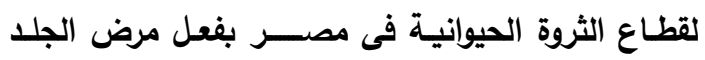
العقدى، حيث قدرت خســائر هذا القطاع نتيجة إصــابة

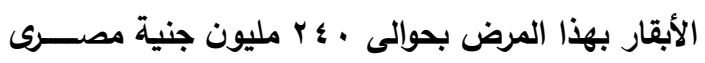

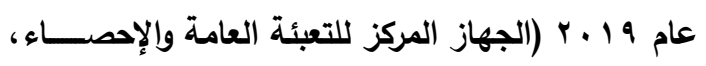

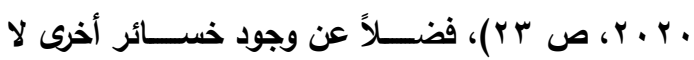

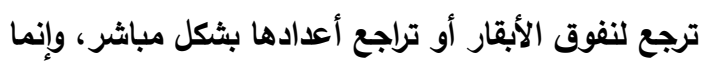

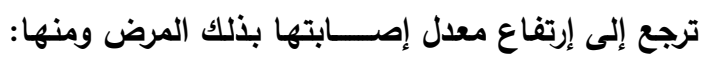

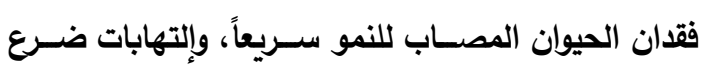

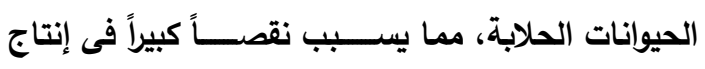

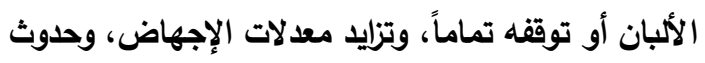

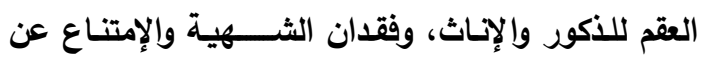

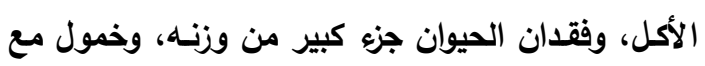

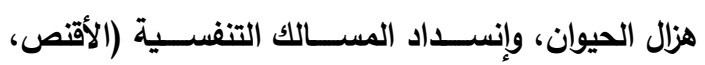

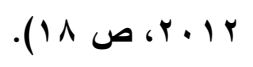

وهو مـا ترتب عليـه نقص المنتجـات الحيوانيـة من

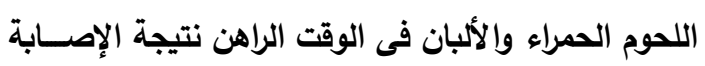

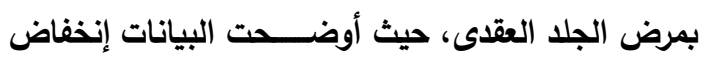

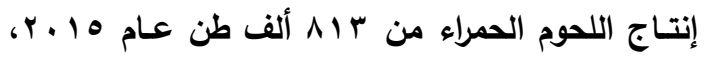


التوصـيات الإرشــادية للوقاية من مرض الجلد العقدى؟،

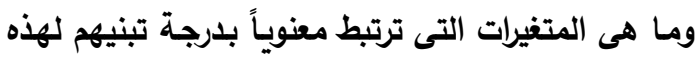

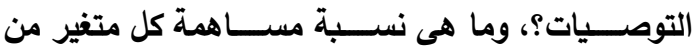

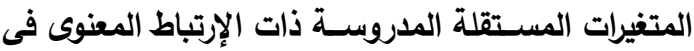
تفسير التباين الكلى الحادث فى درجة تبنى مربى الأبقار

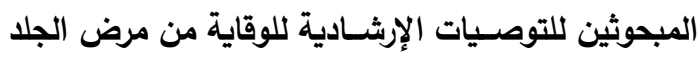

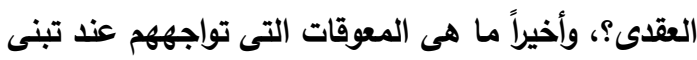
هذه التوصيات من وجهة نظرهم؟، ولا شك أن فى الإجابة

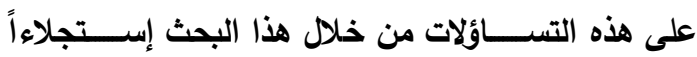

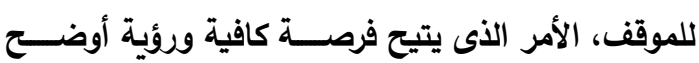

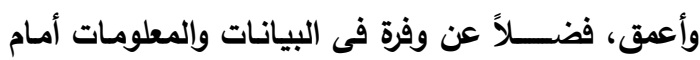

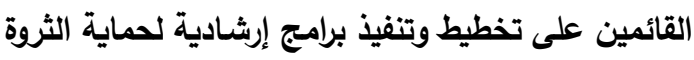
الحيوانية والنهوض بها، لا سـيما فى منطقة البحث لتأتى

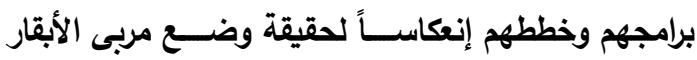

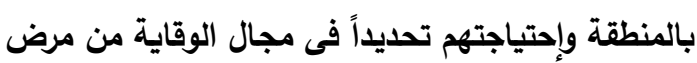

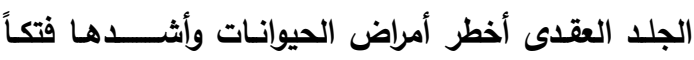
وأوسعها ضراراً وخسارة.

$$
\text { أهداف البحث: }
$$

فى ضوء المشكلة البحثية السابق إبرازها تحددت

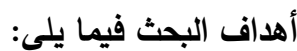
1- التعرف على مستوى تبنى مربى الأبقار المبحوثين للتوصيات الإرشادية للوقاية من الجلد العقدى. r- التعرف على معدل التطبيق الصحيح لمربى الأبقار المبحوثين لكل توصية من التوصيات الإشثادية للوقاية من الجلد العقدى. r- التعرف على مصادر المعلومات التى يستمد منها مربى الأبقار المبحوثين معارفهم عن التوصيات الإرشادية للوقاية من مرض الجلد العقدى. ـ - تحديد العلاقة الإرتباطية بين درجة تبنى مربى الأبقار

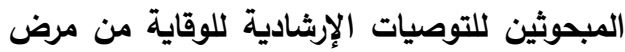

الجلد العقدى والمتغيرات المستقلة المدروسة. هـ تحديد نسبة مساهمة كل متغير من المتغيرات

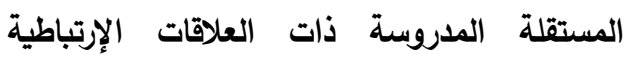
المعنوية فى تفسير التباين الكلى الحادث فى درجة لإنهات
خلا تلــك الفترة (مسليريـة الطب البيطرى بـالغربيـة، $\cdot(r \cdot r \cdot$

ومن منطلق حمـايـة الأبقـار من الأمراض المعديـة

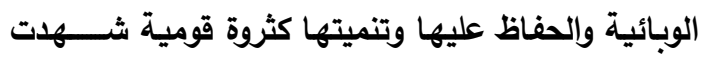

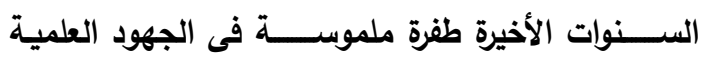

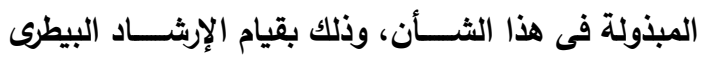

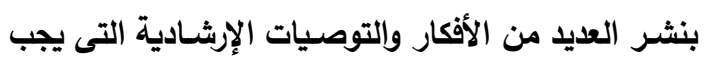

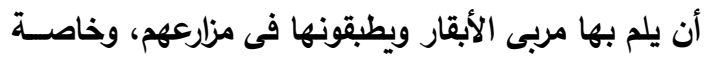

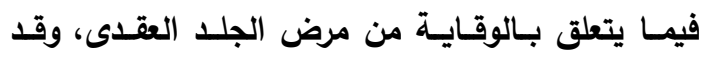

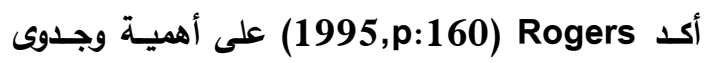

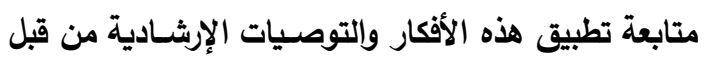
المســتفدين منها وإلا فلا جدوى من الإنفاق على البحث

العلمى.

وعليه يتطلب الأمر جهوداً مكثفة من الإرشاد الزراعى

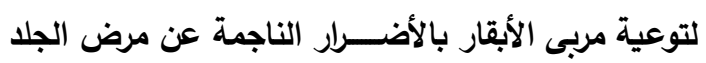

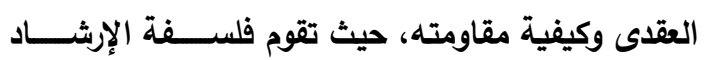

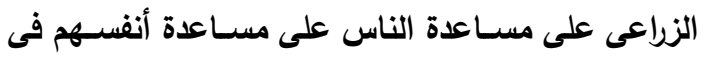
تغيير سـلوكهم التفكيرى والثـعورى والتنفيذى فى مواجهة

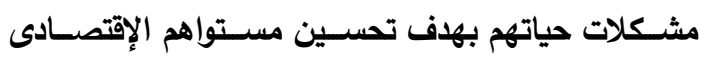

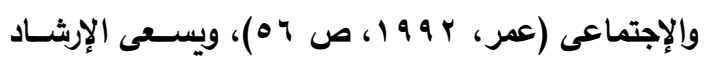

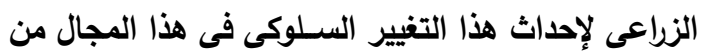

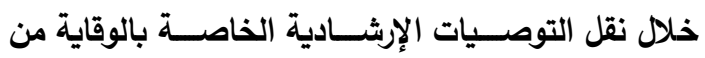

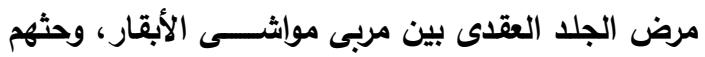
على الأخذ بها، ومساعدتهم على إستخدامها بكفاءة. ولمــا كــان مرض الجلــــ العقــى يعتبر من أهم المشكلات التى تؤثر على الإقتصاد القومى المصرى نظراً

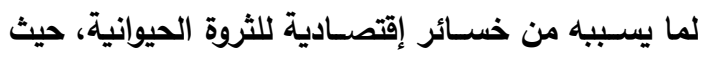
يستنزف الكثير من موارد الدولة لمواجهته، لذا فإن جانباً

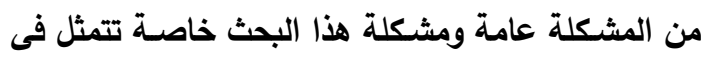

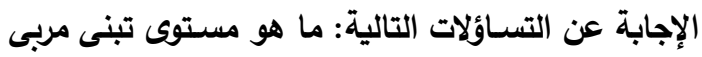

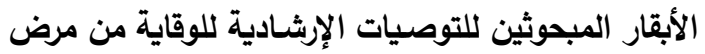

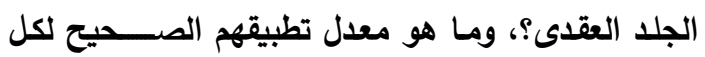
توصية من هذه التوصسيات؟، وماهى مصـادر المعلومات

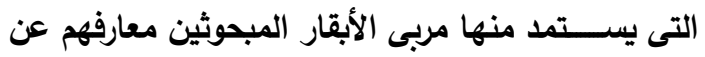


معرفته عن الخبرة حتى إتخاذه قرار بثـــأنها وقبولها أو

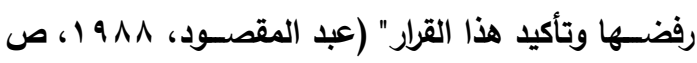

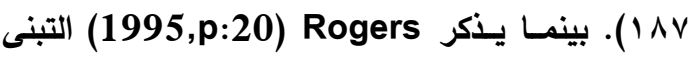
على أنه "العملية التى يمر بها الفرد منذ بلداية معرفته

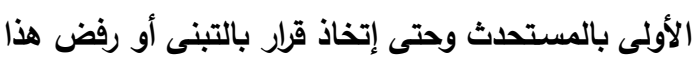
المبتكر ثم تثبيت هذا القرار".

ولما كانت عملية التبنى فى مجال الأفكار المستحدثة

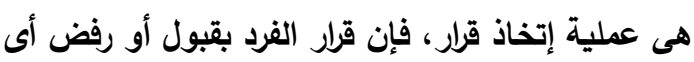

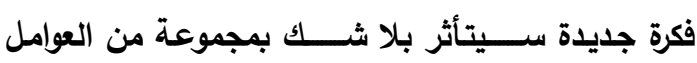

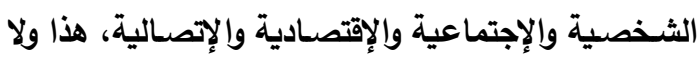

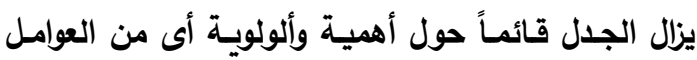

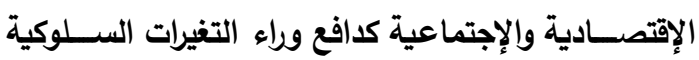

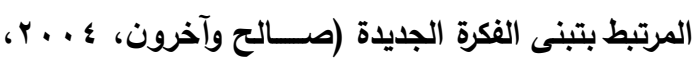

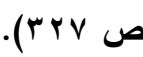

وعليه يمكن تصور مفهوم تبنى التوصيات الإرشادية

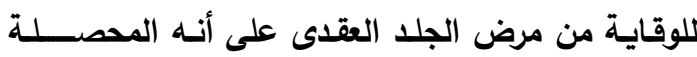

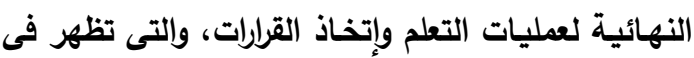
سلوكيات الفرد وتعكسها معارفه وممارساته، وهذا لا شك

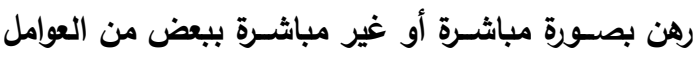

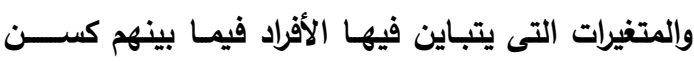

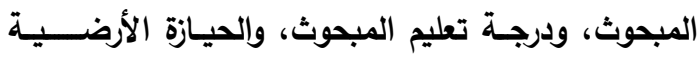

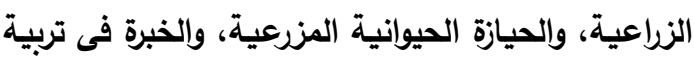
الحيوانات، ودرجة الإتصـال البيطرى، ودرجة قيادة الرأى،

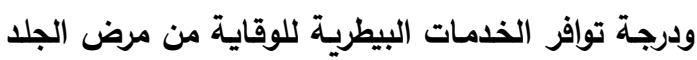

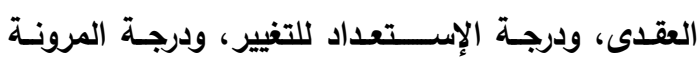

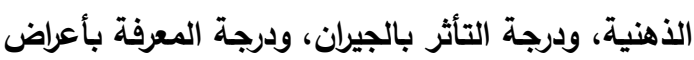

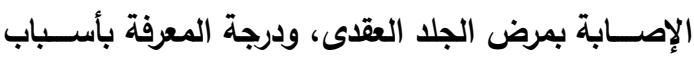
الإصابة بمرض الجلد العقدى.

فمن المعتقد أن عمر الفرد وثيق الصلة بنمط سلوكة

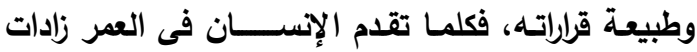

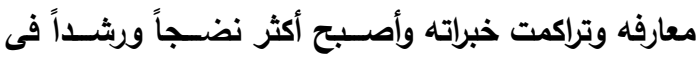

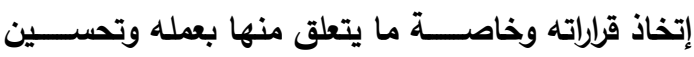

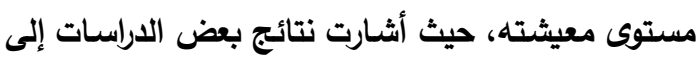
وجود علاقة إرتباطية طردية بين ســـن المبحوث وتبنيه
تبنى مربى الأبقار المبحوثين للتوصيات الإرشادية للوقاية من مرض الجلد العقدى. \- التعرف على المعوقات التى تواجه مربى الأبقار

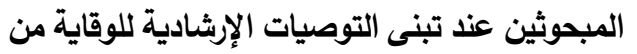
مرض الجلد العقدى من وجهة نظرهم. الأهمية التطبيقية: أتبلور الأهمية التطبيقية لهذا البحث بما يمثله من أحد الإســـهامـات العلمية فى مجال تبنى مربى الأبقار

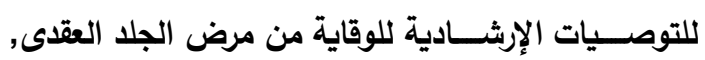

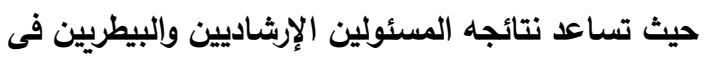
وضــــع وتنفيذ برامج إرثـــادية موجهة إلى مربى الأبقار

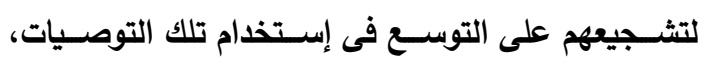

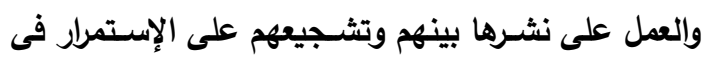

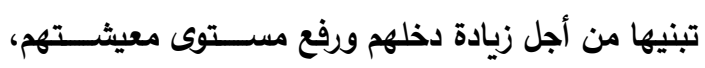

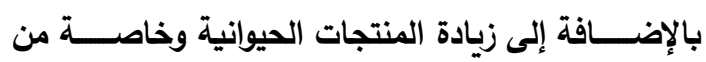

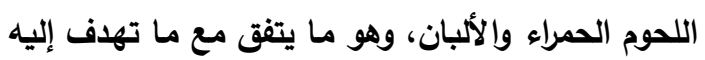

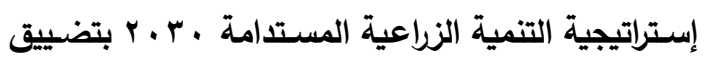
الفجوة الغذائية من البروتين الحيوانى فى مصر.

$$
\text { الإستعراض المرجعى }
$$

يعد تبنى الأفكار والممارسـات الجديدة من أهم الركائز

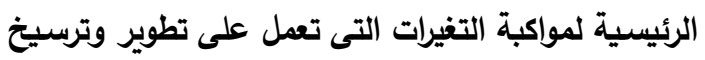

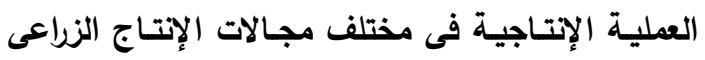

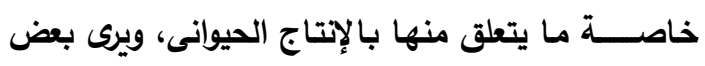

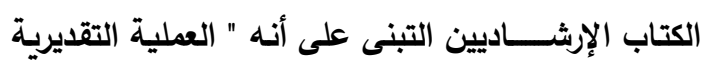

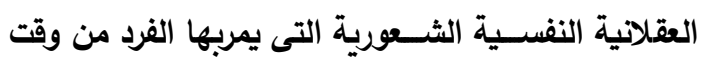
سماعة بفكرة ما حتى الإعتناق التام لها، ورسوخها كجزئ

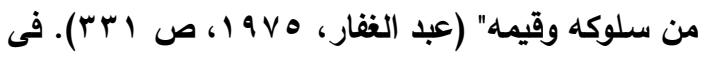

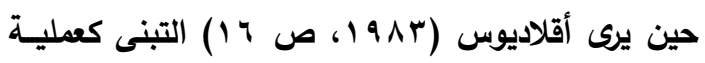

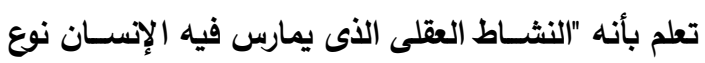
من الخبرة الجديدة التى لم يسبق له أن مر بها". هذا وينظر البعض الآخر إلى التبنى على أنه عملية

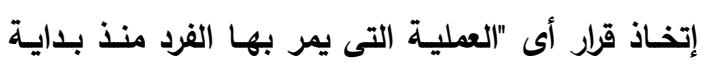


الإجتمـاعيـة بين الزراع، وموشـــراً مهمــاً على قدرتهم الإقتصـادية، وعليه يتوقع أن يزيد حجم الحيازة الحيوانية

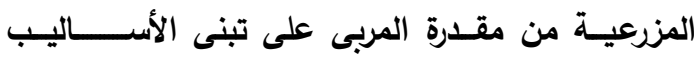
التكنولوجية الجديدة، والتى من بينها التوصيات الإرشادية

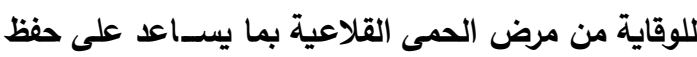

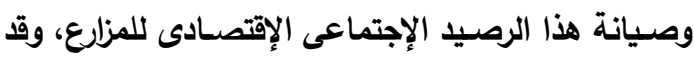

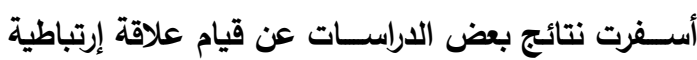
طردية بين حجم الحيازة الحيوانية المزرعية وتبنى الخبرات

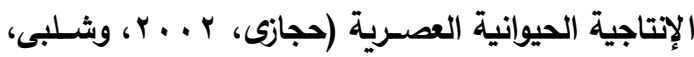

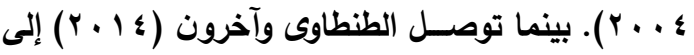

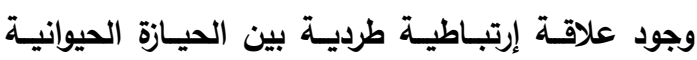

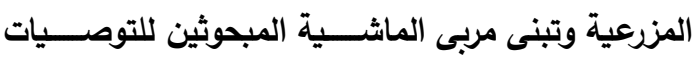
الإرشادية للوقاية من مرض الحمى القلاعية.

\section{ولا يمكن تجاهل الأثر الإيجابى لخبرة مربى الماشــية}

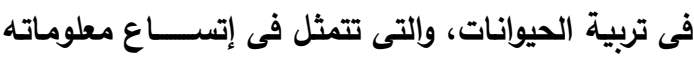

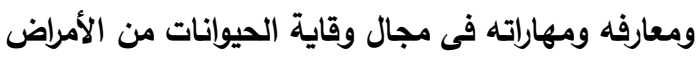

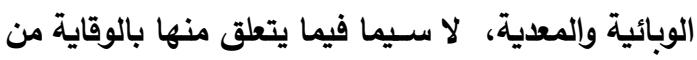

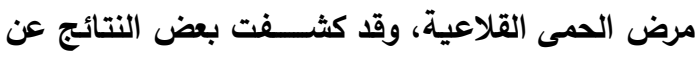
وجود علاقة إرتباطية طردية بين عدد ســنوات الخبرة فى الفى

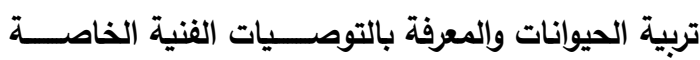

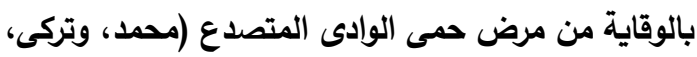

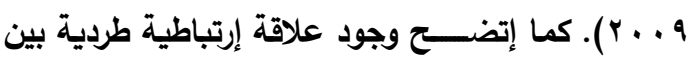

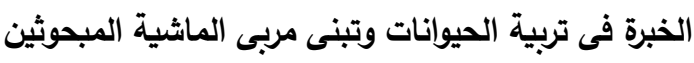

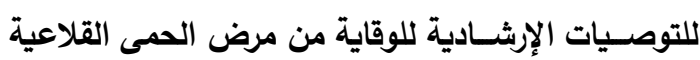
(الطنطاوى وآخرون، ؛ 1 ـ ب).

مما لاثك فيه أن الإتصـال البيطرى يعمل على تزويد

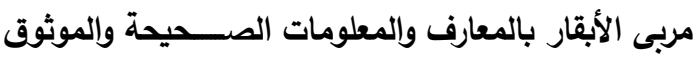

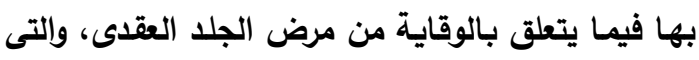

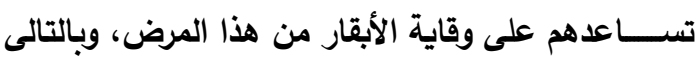

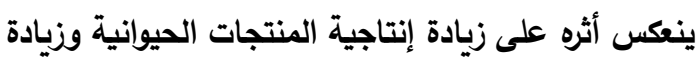

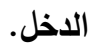

وأن ممارســة قيادة الرأى تتطلب من صـاحبها دراية

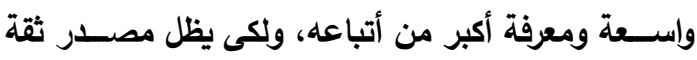

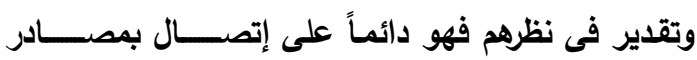

للخبرات الإنتاجية الحيوانية العصـرية (النصـار ، وعثمان،

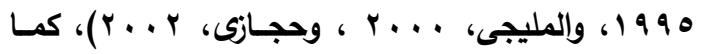
إتضــح وجود علاقة إرتباطية عكسية بين سـن المبحوث وتبنى مربى الماثـية المبحوثين للتوصـيات الإرثـادية للوقاية من مرض الحمى القلاعية (الطنطاوى وآخرون،

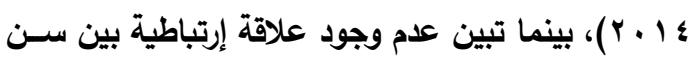

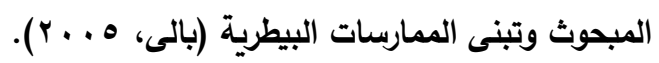
ويعد التعليم أحد الوســـائل الهامة للفرد فى المجتمع المعاصـر لتحصـيل المعارف وإكتســاب المهارات العلمية

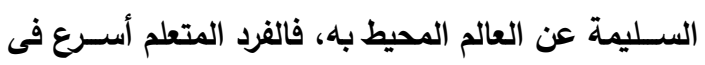

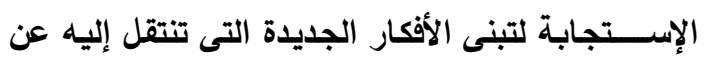

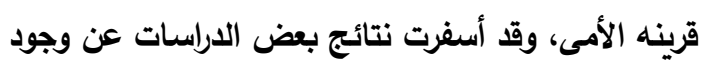

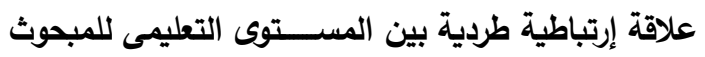

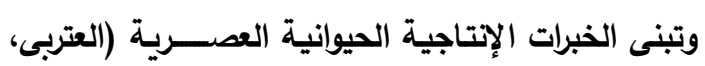

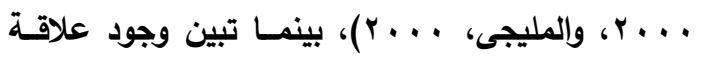

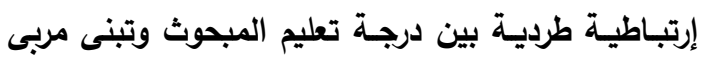

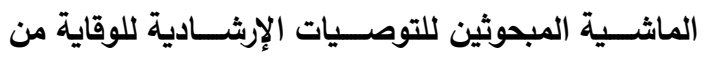

$$
\text { مرض الحمى القلاعية (الطنطاوى وآخرون، ؛ } 1 \text { ـ r). }
$$

وتعتبر مســاحة الحيازة الأرضــية الزراعية مؤشــــاً

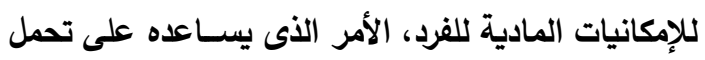

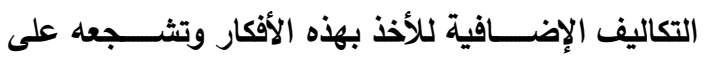

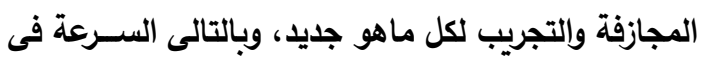

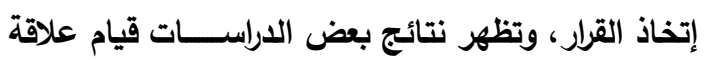

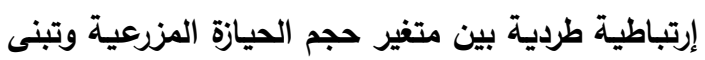

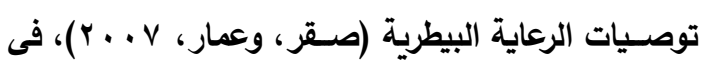

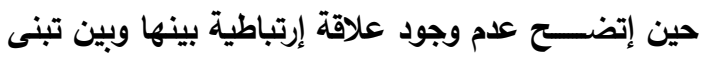

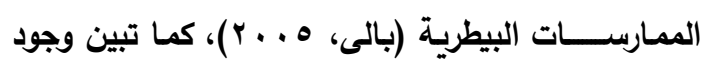
علاقة إرتباطية طردية بين الحيازة الأرضـــية المزرعية وتبنى مربى الماثـية المبحوثين للتوصـيات الإرثـادية للوقاية من مرض الحمى القلاعية (الطنطاوى وآخرون، . $r \cdot 1 \leqslant$ وتمثل الحيازة الحيوانيـة المزرعية هى الأخرى مورد

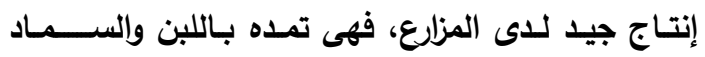
العضـــوى والعائد النقدى، كما تعد رمزاً من رموز المكانة فئة ولئل 
على الأثـــياء تؤدى إلى تبنى الأفكار الجديدة، حيث أن

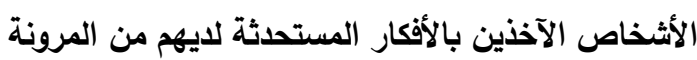

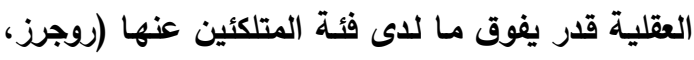

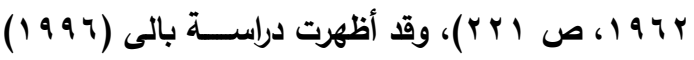
أن هناك علاقة طردية موجبة بين درجة المرونة الذهنية وتبنى تكنولوجيا النهوض بالإنتاج الحيوانى. ويعد تأثر الفرد بجيرانـه فى تقليدهم للممـارســــات

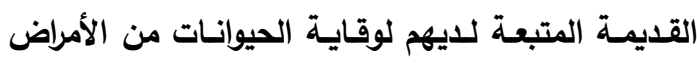

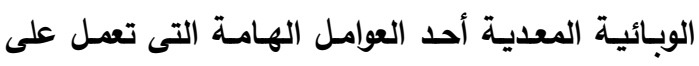
الوقوف فى ســبيل تبنيه للتكنولوجيات الحيوانية الجديدة

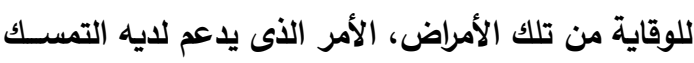

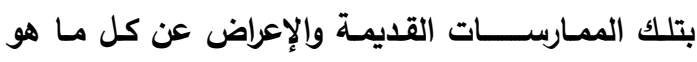
مستحدث، وخاصـة ما يتعلق بتبنى التوصيات الإرشـادية للوقاية من مرض الجلد العقدى فى الأبقار.

$$
\text { فروض البحث: }
$$

لتحقيق هدفى البحث الرابع والخامس تم صـــياغة الفرضين البحثيين التاليين: 1- توجد علاقة إرتباطية بين درجـة تبنى مربى الأبقار

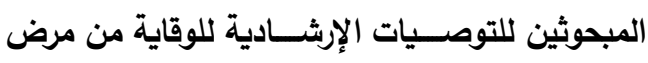
الجلد العقدى والمتفيرات المستقلة المدروسـة التالية: ســن المبحوث، ودرجـة تعليم المبحوث، والحيـازة

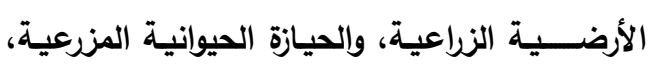

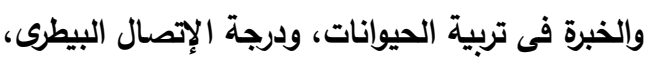
ودرجة قيادة الرأى، ودرجة توافر الخدمات البيطريسة

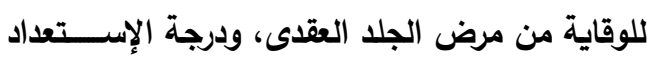

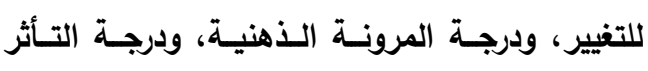

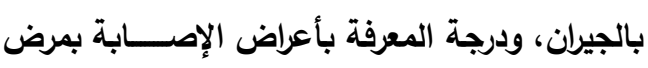

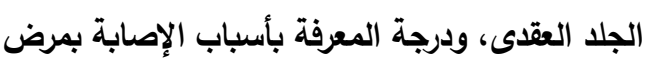

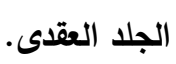

r- تســهم المتغيرات المسـتقلة المدروســة ذات العلاقات

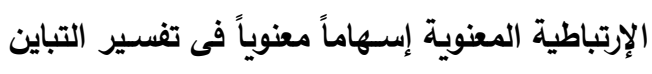

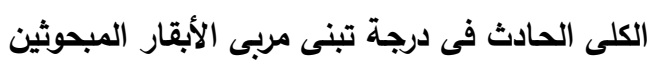
للتوصيات الإششادية للوقاية من مرض الجلد العقدى.

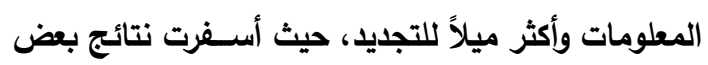

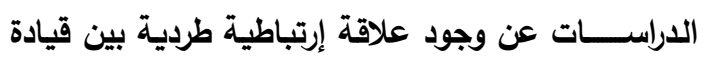

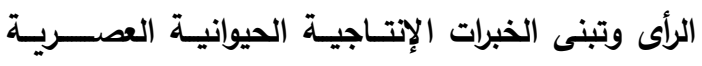

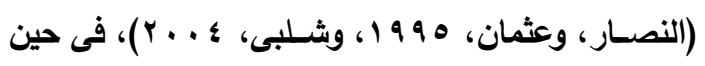
تبين وجود علاقة إرتباطية طردية بين قيادة الرأى وتبنى

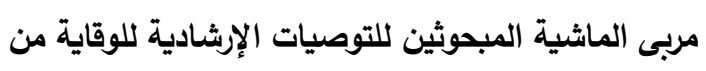
مرض الحمى القلاعية (الطنطاوى وآخرون، ـ ا ـ ب). ومن الجدير بالذكر أن يساعد توافر الخدمات البيطرية

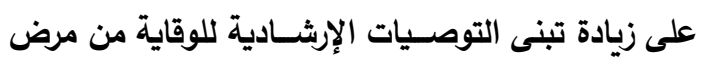

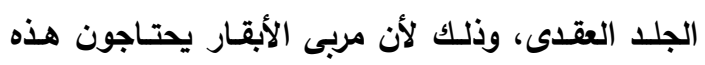
الخذمات فى مجتمعاتهم المحلية إذ يصعب عليهم الإتتقال

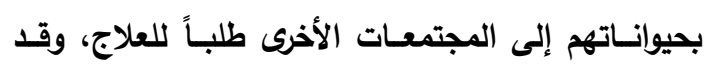
توصـلـل بالى (ه . . ب) إلى وجود علاقة إرتباطية طردية

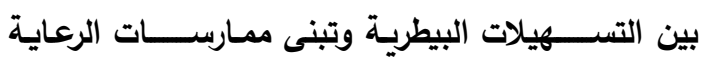
البيطرية. كما تبين وجود علاقة إرتباطية طردية بين توافر

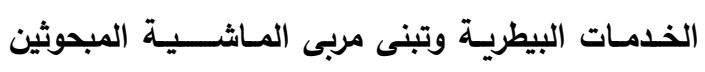
للتوصـيات الإرشــادية للوقاية من مرض الحمى التهى القلاعية

$$
\text { (الطنطاوى وآخرون، ؛ ا + r). }
$$

وأن إبـــــعداد الفرد للتغيير إنمـا يتوقف على قبوليه

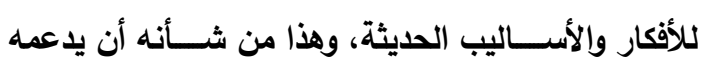

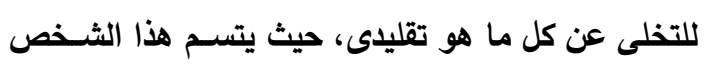

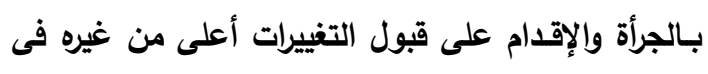

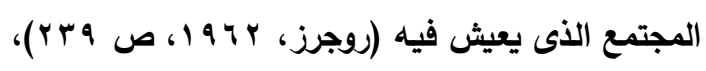

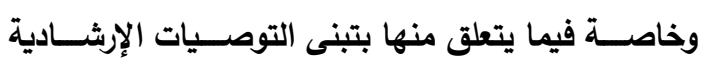
للوقاية من مرض الجلد العقدى فى الأبقار. ولا يمكن إغفال أن المرونة الذهنية تعمل على تحرر

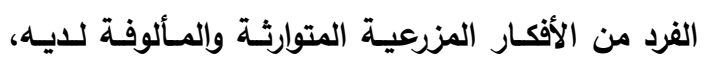

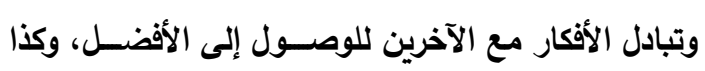

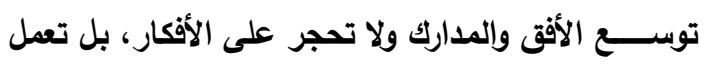
على الإنفتـاح على كل أفراد المجتمع وشـــــى الأفكار

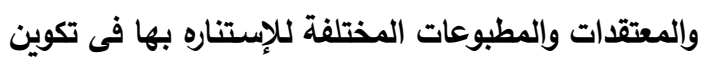
البناء المعرفى السليم، ومن ثم يؤلدى إلى الحكم الصحيح

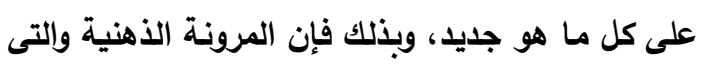
من نواتجها تحكيم العقل وإلتســبب المنطقى فى الحكم 


$$
\text { ثانياً: منطقة البحث: }
$$

أجرى هذا البحث فى مركزى المحلة الكبرى، وكفر

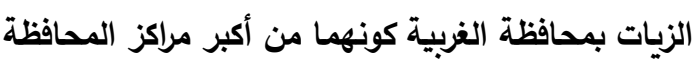

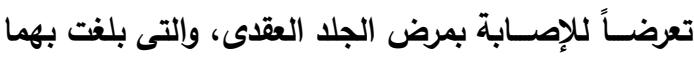

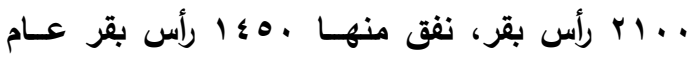

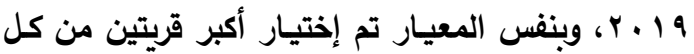

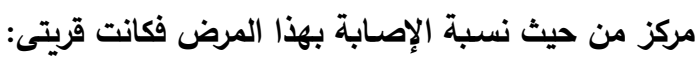

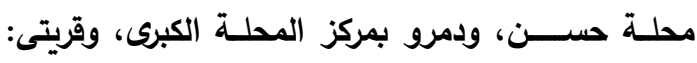

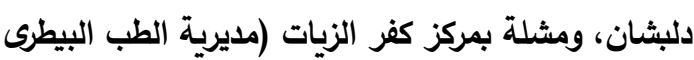

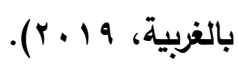

ثالثاً: شاملة البحث وعينته: تضمنت شـاملة هذا البحث جميع مربى الأبقار بالقرى

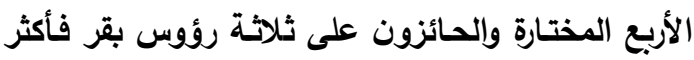
والبالغ عددهم . . 1 مربياً، وتم تحديد حجم عينة البحث

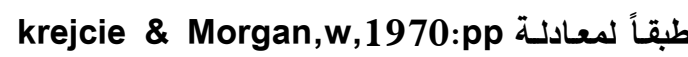

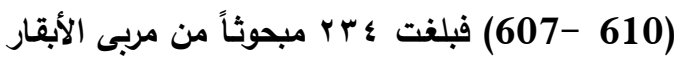
يمثلون نسبة qج\% من إجمالى الثاملة، وقد تم إختيارهم

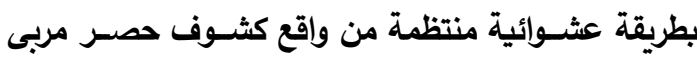

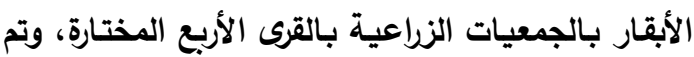

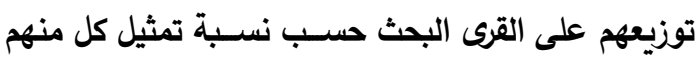
فى الثاملة كما هو موضح بجدول رقم (1).
وقد تم إختبار هذين الفرضين فى صورتهما الصفرية الطريقة البحثية أولاً: التعاريف الإجرائية للمصطاحات المستخدمة بالبحث: 1- مرض الجلد العقدى: يقصـــــ به فى هذا البحث بأنه

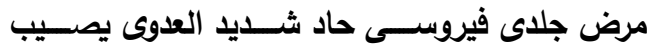

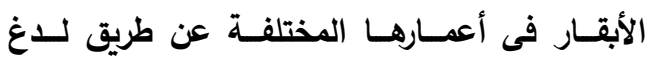

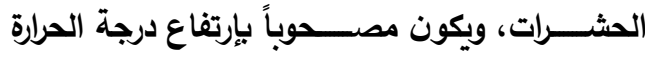

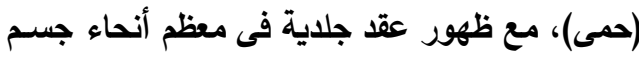

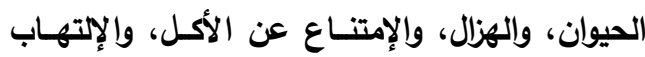
الرئوى، مسبباً لها خسائر إقتصادية كإنخفاض إنتاج اللبن، والإجهاض، والعقم، وتلف الجلد. r- مربي الأبقار : يقصــــ بهم فى هذا البحث كل مبحوث يحوز ثلاثـة رؤوس فـأكثر من الأبقـار قبـل ثلاث فئل سنوات من تاريخ إجراء البحث. rـ المتبنى: يقصــــ به فى هذا البحث بالمبحوث الذى

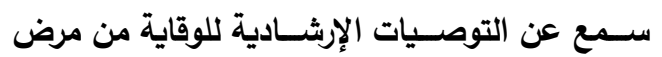
الجلد العقدى، وقام بالتطبيق الفعلى لها لمدة لا تقل

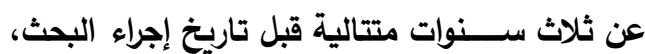
ويرغب الإستمرار فى تطبيقها.

\begin{tabular}{|c|c|c|c|c|c|}
\hline \multirow{2}{*}{ الإجمالى } & \multicolumn{2}{|c|}{ كفر الزيات } & \multicolumn{2}{|c|}{ المحلة الكبرى } & المركز \\
\hline & مثلة & دلبثان & دمرو & محلة حسن & القرى المختارة \\
\hline 7. & $|r|$ & $10 \leqslant$ & $1 \leqslant$. & 110 & الثاملة \\
\hline צ & $\varepsilon v$ & 7. & 00 & Vr & العينة \\
\hline
\end{tabular}

جدول رقم ( ) : توزيع شاملة البحث وعيتته على القرى موضع الدراسة.

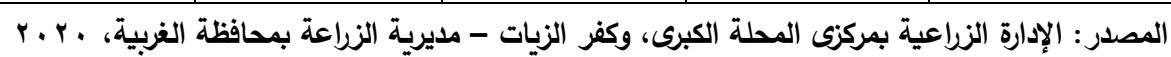

رابعاً: أسلوب جمع البيانات: 
إلى أقل من ســـنتين)، والعجلة الجاموس (أقل من

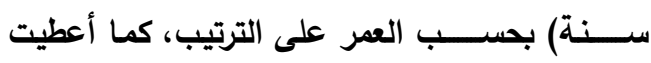

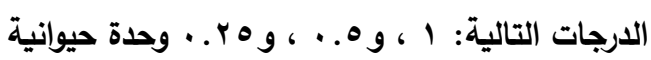

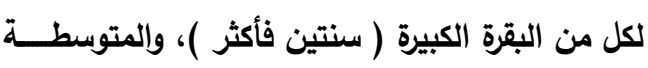

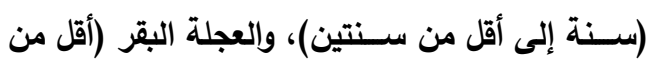

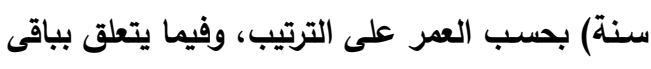

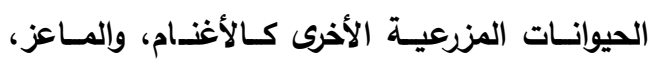

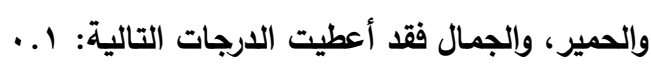

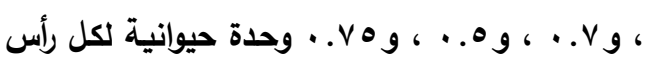

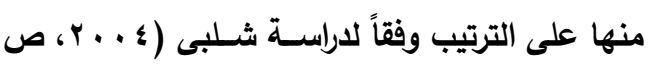

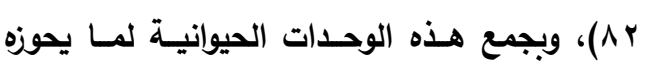

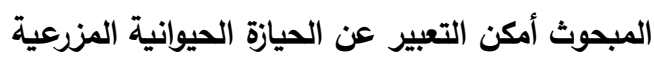

هـ الخبرة فى تربيـة الحيوانـات: قيس هذا المتغير من خلال إجابة المبحوث عن المدة الزمنية التى قضــاها فى تربيـة الحيوانـات حتى وقت إجراء البحث معبراً عنها بعدد السنوات.

- - درجة الإتصـال البيطرى: قيس هذا المتغير من خلال

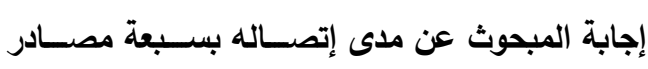
إتصــالية تعكس إتصــاله البيطرى فيما يتعلق بوقاية

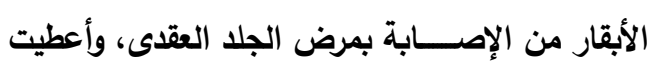

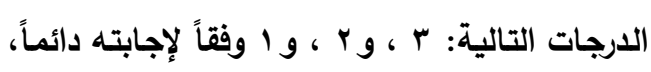

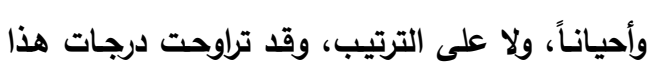

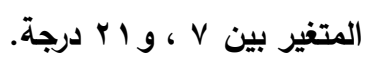

درجة قيادة الرأى: قيس هذا المتغير من خلال إجابة

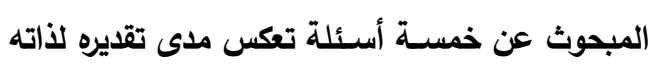

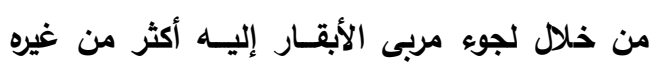

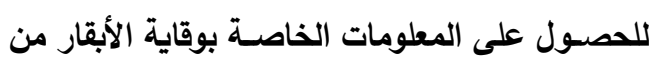
الإصـــابة بمرض الجلد العقدى، وكذا توصـــيل ونقل

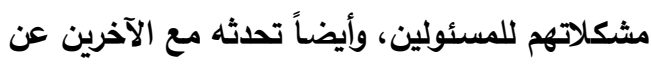
الوقاية من مرض الجلد العقدى، ومحاولته إقناعهم

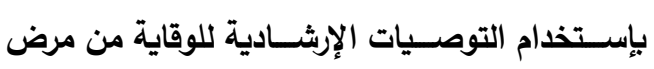

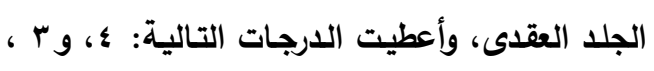

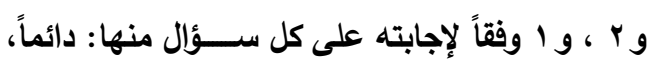

تم إسـتخدام إســمارة إسـتبيان بالمقابلة الثـخصـية

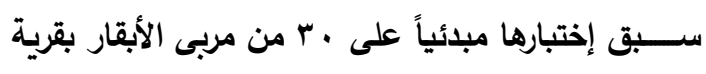

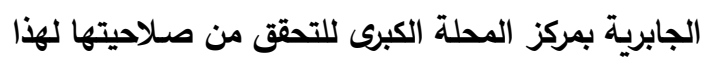

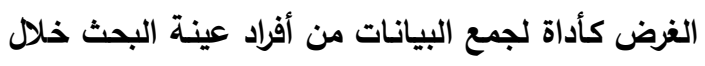

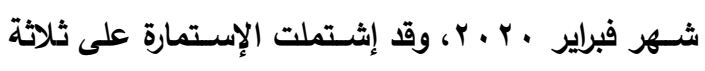

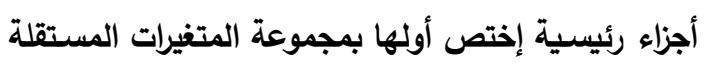

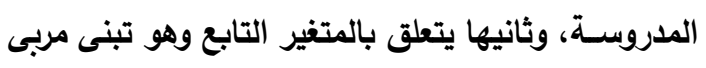

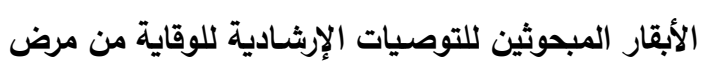

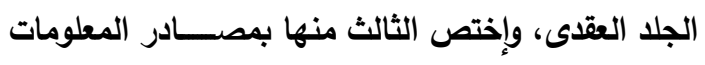

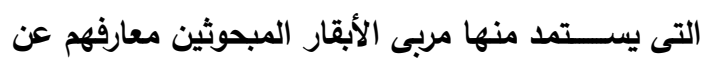

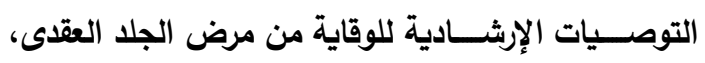

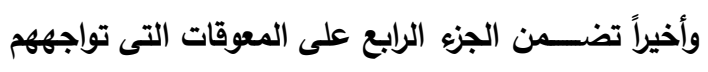

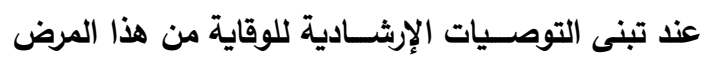
من وجهة نظرهم.

خامساً: المتغيرات البحثية وكيفية قياسها: 1- ســـن المبحوث: قيس هذا المتغير بعداد ســـنوات

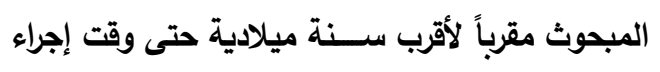
البحث. (البغ. r- - درجة تعليم المبحوث: قيس هذا المتغير بعدد سنوات

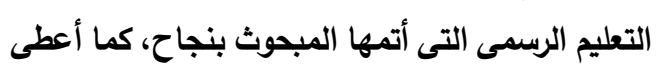
الأمى درجة واحدة، ولمن يقرأ ويكتب ؛ درجات.

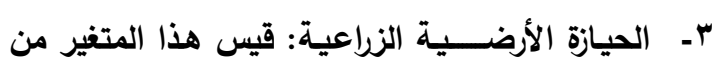
خلال إجابة المبحوث عن إجمالى الحيازة التى يحوزها

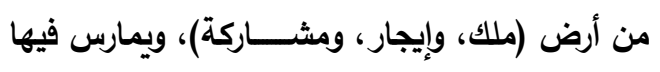
نثـــاطه الزراعى حتى وقت إجراء البحث معبراً عنها

بالقيراط.

צ- الحيـازة الحيوانيـة المزرعيـة: قيس هذا المتغير من

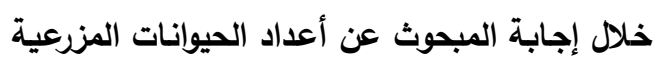

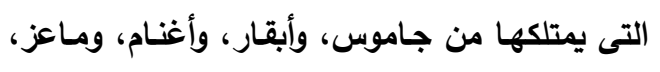

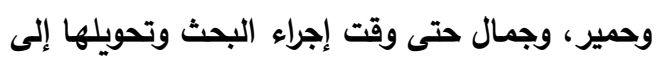

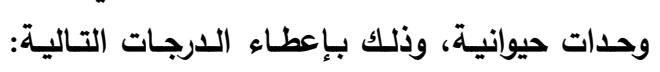

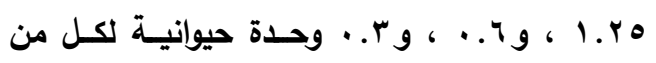

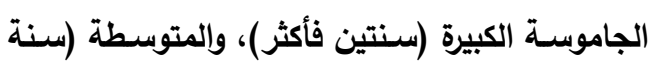


11- درجـة التأثر بالجيران: قيس هذا المتغير من خلال إجابة المبحوث عن ســبع عبارات تعكس مدى تأثره بجيرانه فى قريته وتقليده للمارســات القديمة المتبعة

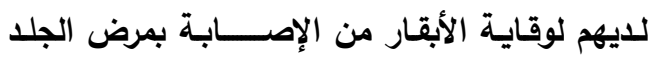

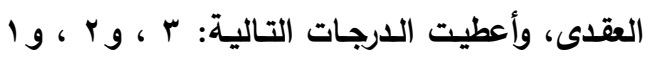

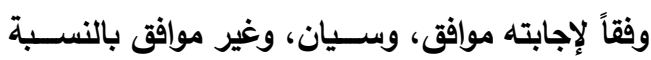

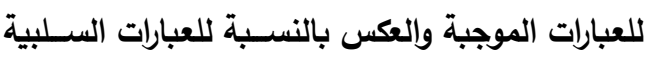
على الترتيب، وقد تراوحت درجات هذا المتغير بين

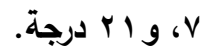
r ا - درجة المعرفة بأعراض الإصابة بمرض الجلد العقدى:

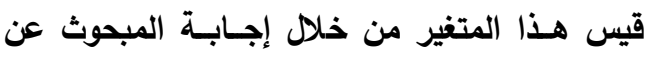

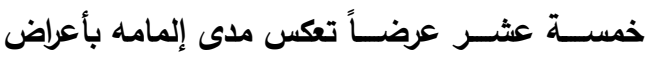

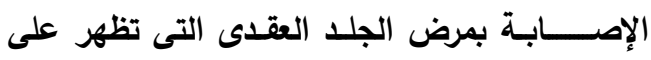
الأبقـار، وأعطيت الدرجـات التـاليـة: ب، و ا وفقاً لإجابته على كل عرض منها: يعرف، ولا يعرف على

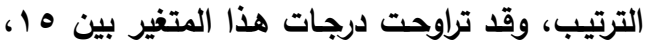

$$
\text { و · r درجة. }
$$

r ا - درجة المعرفة بأسباب الإصـابة بمرض الجلد العقدى:

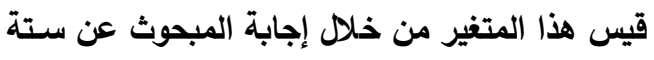
أسـباب تعكس مدى إلمامه بأســباب إصـابة الأبقار بمرض الجلد العقدى، وأعطيت الدرجات التالية: ؟،

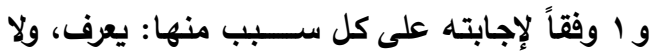

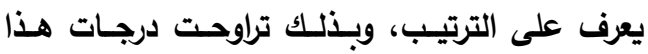

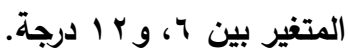
؛ ا - درجـة تبنى مربى الأبقـار المبحوثين للتوصـــيـات

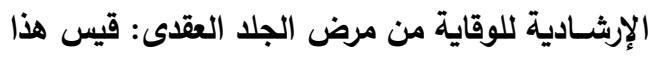
المتغير من خلال إجابة المبحوث عن ثلاثتة محاور

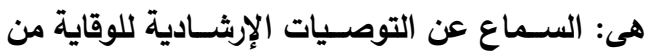

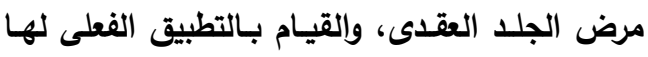
لمدة لا تقل عن ثلاث سنوات متتالية قبل تاريخ إجراء

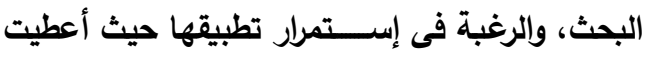

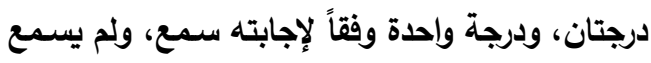
على الترتيب، وكذلك درجتان، ودرجـة واحدة وفقـاً
وأحياناً، ونـادراً، ولا على الترتيب، وبـذلك تراوحت درجات هذا المتغير بين ه ، و ـ ب درجة. ^- درجة توافر الذدمات البيطرية للوقاية من مرض الجلد العقدى: قيس هذا المتغير من خلال إجابة المبحوث عن مدى توافر أربع خدمات بيطرية خاصــــة بوقاية الإية الأبقار من الإصــــابة بمرض الجلد العقدى يقدمها الجهاز البيطرى بمنطقـة البحث، والتى يعتقد أنها لالتها تســـاعده فى مقاومة هذا المرض، وأعطيت الدرجات

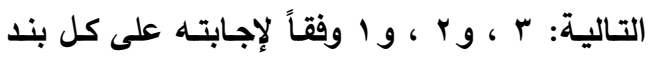

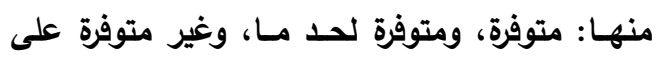

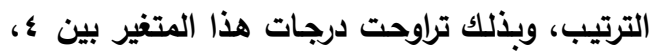

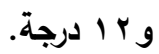
9- درجة الإسـتعداد للتغيير : قيس هذا المتغير من خلال

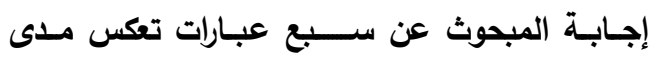
إستعداده لتنفيذ أى فكرة جديدة خاصـة بوقاية الأبقار

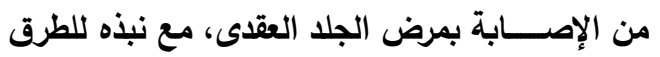
التقليدية أو تمســكه بها، وكذلك مدى أســبقيته فى الإنى

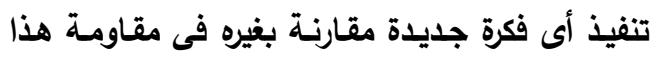

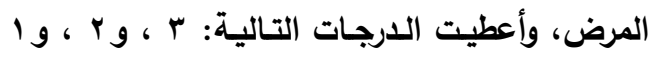
وفقاً لإجابته على كل عبارة منها: أنفذها فوراً، وأنتظر لما حد غيرى ينفذها، ولا أنفذها، بالنســـــة للعبارات الموجبة وإلعكس للعبارات السـالبة على الترتيب، وقد تراوحت درجات هذا المتغير بين V ، و اب درجة. • 1ـ درجة المرونـه الذهنية: قيس هذا المتغير من خلال إجابة المبحوث عن ثمانى عبارات تعكس مدى تحره من الأفكار القديمة والمتوارثة لديه، والأخذ بالأفكار

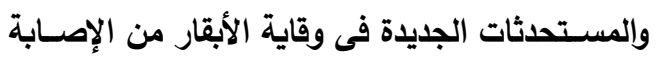

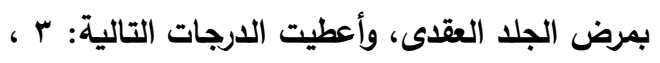

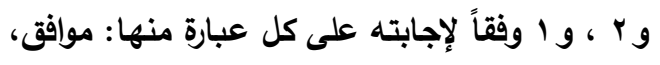

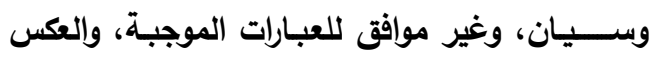
بالنسبة للعبارات السالبة على الترتيب، وبذلك تراوحت درجات هذا المتغير بين ^، و ك ب درجة. 
فى أماكن إيواء الأبقار بالمبيدات الحثـــرية، وتغذية

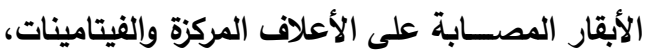
ووضــع الأبقار المصــابة فى الحجر البيطرى لمدة r

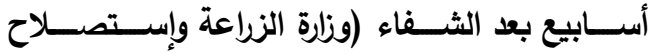

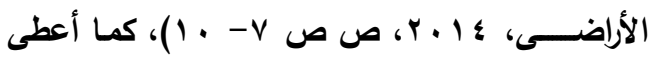
المبحوث أيضــــاً درجتان، ودرجة وإحدة وفقاً لإجابته

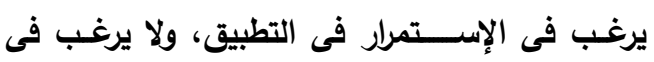

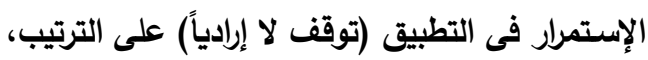
وتعبر الارجة الإجمالية التى حصـل عليها المبحوث

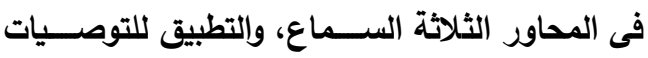
الإرشــادية الثمانى عثــر، والرغبة للإســتمرار فى التى التطبيق مجتمعة عن الارجة الكلية لتبنيه للتوصـيات

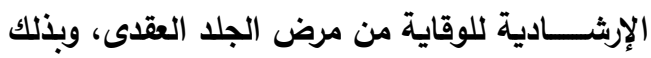

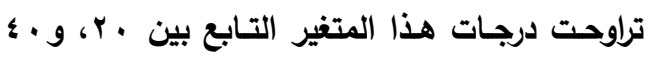
درجة. ووفقاً لدرجات تبنى مربى الأبقار المبحوثين

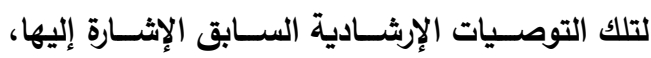

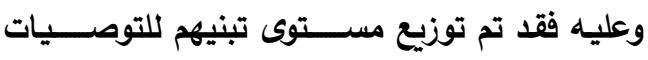
الإرثــادية للوقاية من مرض الجلد العقدى إلى ثلاث

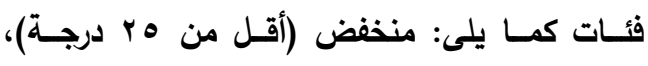

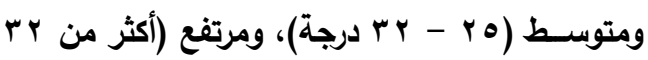
درجة).

1 1 - معدل التطبيق الصـيح لكل توصـية من التوصسيات

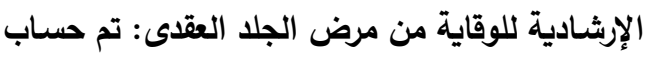

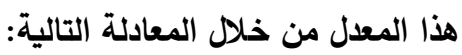

لإجابته طبق التوصيات الإرشسادية للوقاية من مرض الجلا العقدى بثــكل صـــيح، ولم يطبق بالثـــكل الصحيح على الترتيب، وذلك من خلال إتاحة الفرصة للمبحوث لإختيار الإجابة الصـحيحة من بين الإختيار

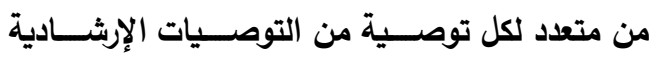

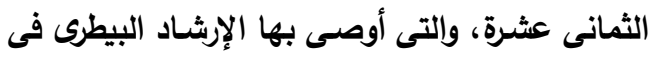

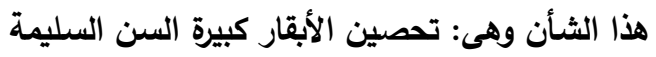

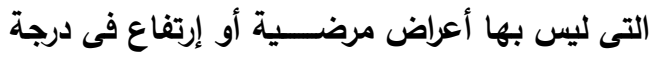

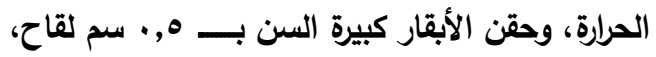

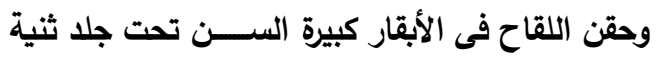
الذيل، وتحصـين عجول الأبقار الصــيرة بعد الولادة من Y I - 17 إسبوع، وحقن عجول الأبقار الصغيرة

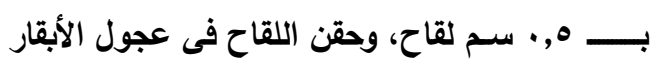
الصغيرة تحت جلد ثنية الذيل، وتحصين الأبقار كبيرة

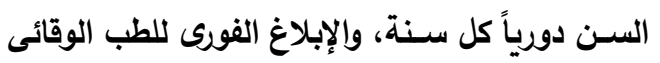

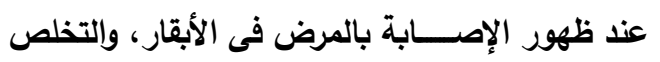

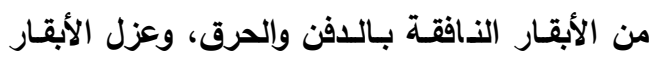
المصـــابـة فى أمساكن إيواء بعيدة، وتطهير الأبقار

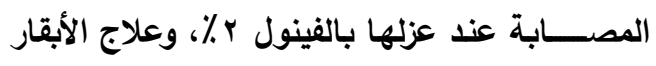

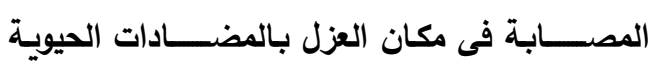

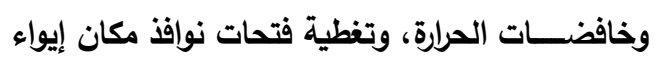

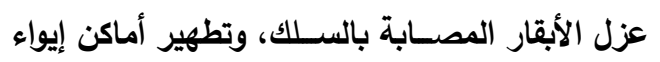

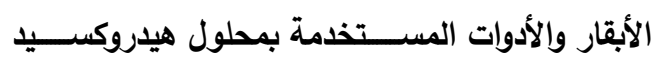

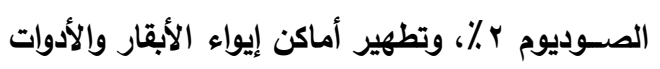

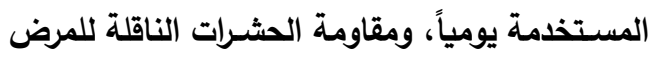

\section{عدد مربى الأبقار المبحوثين الذين طبقوا كل توصية من التوصيات}

الإرشادية للوقاية من مرض الجلد العقدى تطبيقاً صحيحاً

$x, \ldots$ معدل التطبيق الصحيح =

إجمالى عدد مربى الأبقار المبحوثين ( ؟ ؟ F ) 
Menoufia J. Agric. Economic \& Social Sci. Vol. 5 May (2020): 155 - 180

بأعراض الإصابة بمرض الجلد العقدى متوسطة، فى حين

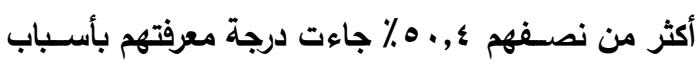
الإصابة بمرض الجلد العقدى منخفضة.

ويتضــح مما ســق إرتفاع نسـبة كبار السـن، وكذا نســبة الأمية، ودرجة التأثر بالجيران بين مربى الأربقار

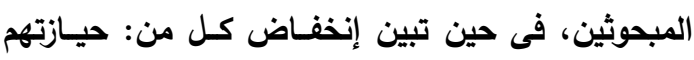

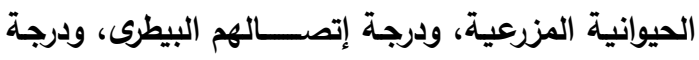
توفر الخدمات البيطرية المقدمة لهم، وإستعدادهم للتغيير،

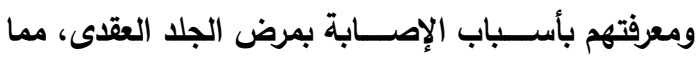

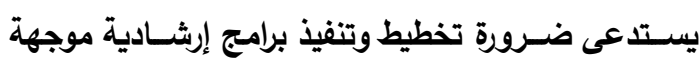

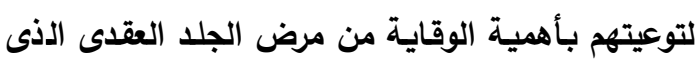

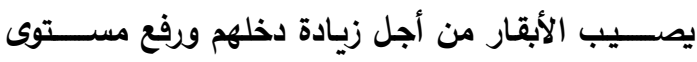

معيشتهم خاصة بالمنطقة، أو مركزى موضوع البحث.

\section{النتائج ومناقشتها}

أولاً: مستوى تبنى مربى الأبقار المبحوثين للتوصيات الإرشادية للوقاية من مرض الجلد العقدى:

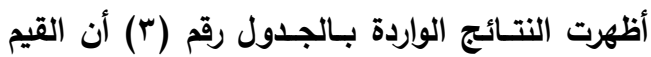
الرقميـة الفعليـة الكليـة لتبنى مربى الأبقـار المبحوثين

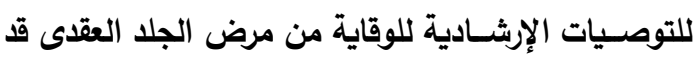

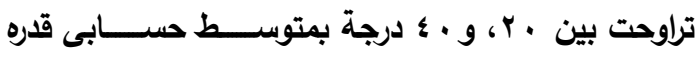

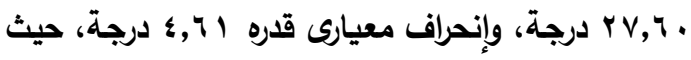

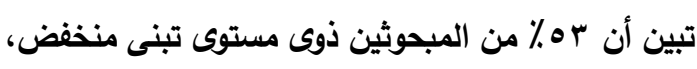

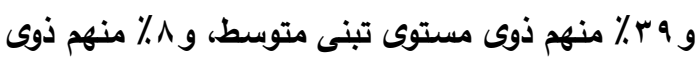

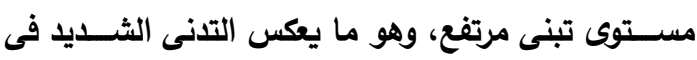
تبنى مربى الأبقار المبحوثين لتلك التوصيات، الأمر الأى وهي

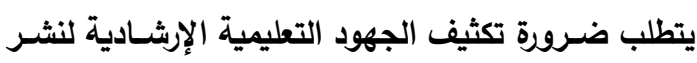
المعارف والخبرات المرتبطة بتطبيق التوصيات الإرشـادية

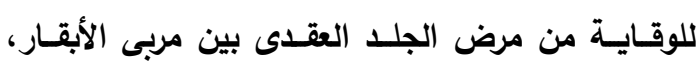

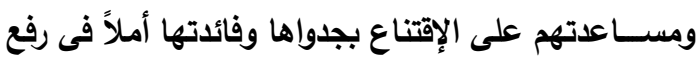

مستوى تبنيهم لها.
وعليه فقد تم تصنيف تلك التوصيات وفقاً لمعدلات تطبيقها الصحيح إلى ثلاثة مستويات كما يلى:

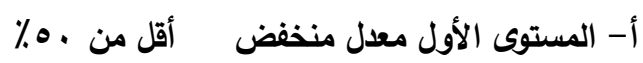

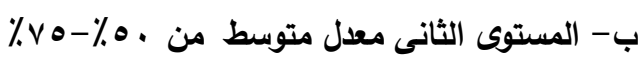

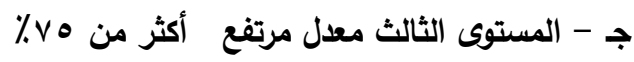
سادساً: أسلوب تحليل البيانات: أســتخدم العرض الجدولى بالتكرار والنســب المئوية، والمتوسط الحسابى، والإحراف المعيارى، ومعامل الإرتباط البسـيط لبيرسـون، ونموذج التحليل الإرتباطى والإحدارى والإنيط المتعدد المتدرج الصــــاعد (Step-wise) فى تحليل البيانات وعرض نتائج البحث. سابعاً: وصف عينة البحث:

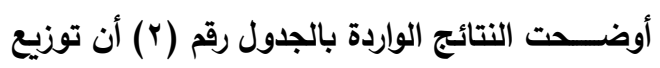

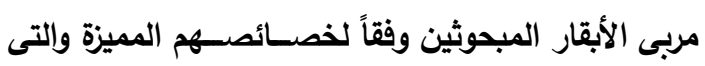

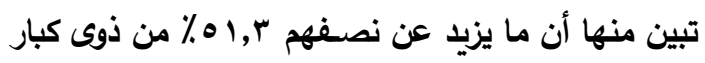

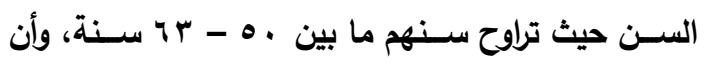

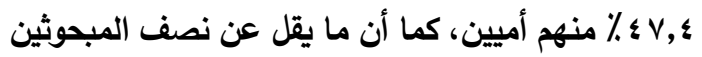

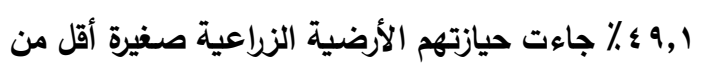

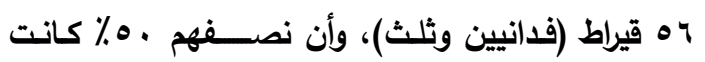

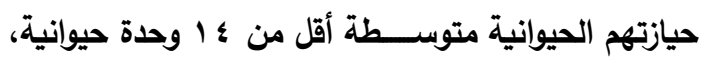

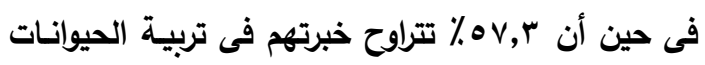

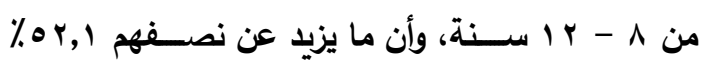

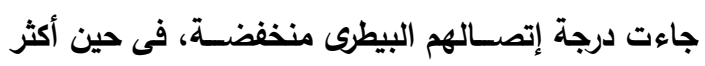

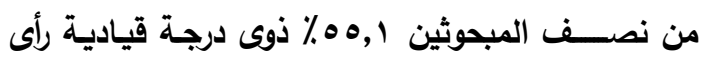

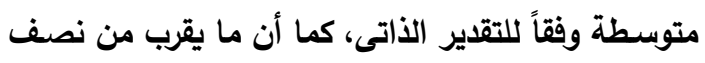

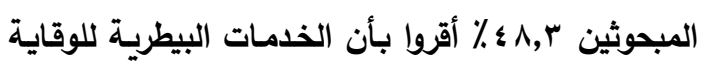

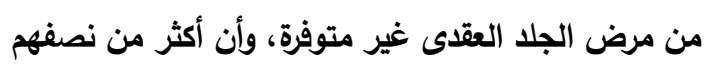

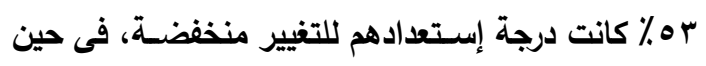

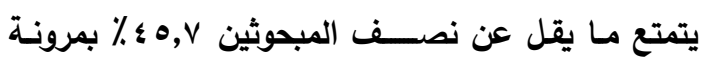

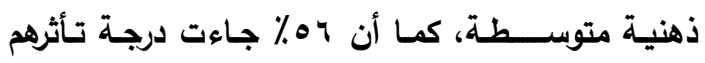

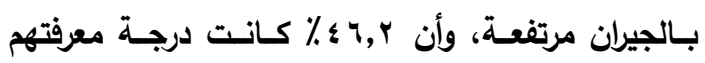


جدول رقم (Y): توزيع مربى الأبقار المبحوثين وفقاً لخصائصهم المميزة.

\begin{tabular}{|c|c|c|c|c|}
\hline ملاحظات & $\%$ & العدد & الخصائص & p \\
\hline & & & سن المبحوث: المن & 1 \\
\hline ا بr - r r سنة & $1 \cdot, v$ & ro & شباب ( أقل من هr سنة ) & \\
\hline 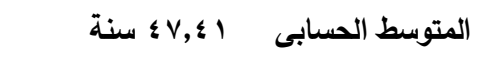 & $r \Lambda,$. & $\wedge 9$ & متوسط ( هץ - .0 سنة ) & \\
\hline \multirow[t]{2}{*}{ 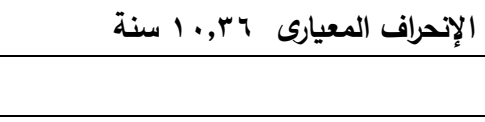 } & $01, r$ & ir. & كبير ( أكثر من • سنة ) & \\
\hline & $1 \ldots$ & $r r \leq$ & الإجمالى & \\
\hline \multirow{9}{*}{ 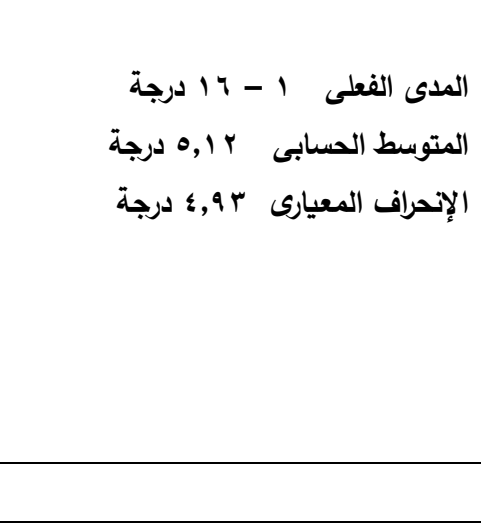 } & & & درجة تعليم المبحوث: & r \\
\hline & $\varepsilon v, \varepsilon$ & 111 & & \\
\hline & $\mid r, \Lambda$ & r. & يقرأ ويكتب & \\
\hline & 11,1 & rq & 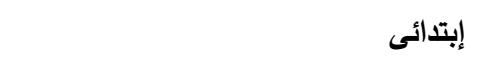 & \\
\hline & $1 \cdot, r$ & $r \varepsilon$ & 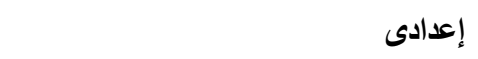 & \\
\hline & $\uparrow, \xi$ & 10 & ثانوى & \\
\hline & $v, r$ & iv & فوق متوسط & \\
\hline & $\varepsilon, v$ & 11 & 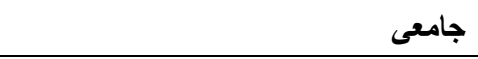 & \\
\hline & $1 \ldots$ & $r r \leq$ & الإجمالى & \\
\hline \multirow{5}{*}{ 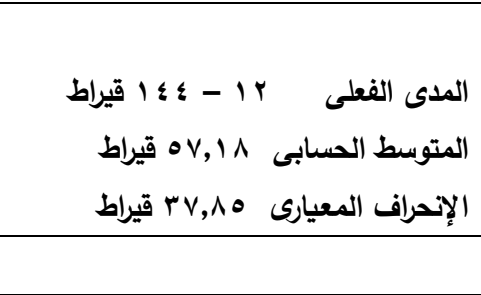 } & & & الحيازة الأرضية الزراعية: & $r$ \\
\hline & $\leq 9,1$ & 110 & صغيرة أقل من كه قيراط ) & \\
\hline & $\varepsilon r, \vee$ & $1 \ldots$ & متوسطة ( צه - ... & \\
\hline & $\wedge, 1$ & 19 & كبيرة ( أكثر من .. 1 قيراط ) & \\
\hline & $1 \ldots$ & $r r \leq$ & الإجمالى & \\
\hline \multirow{5}{*}{ 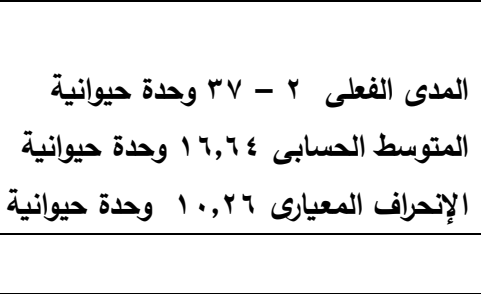 } & & & الحيازة الحيوانية المزرعية: & $\varepsilon$ \\
\hline & $\varepsilon \cdot, 4$ & 90 & منذفضة ( أقل من ؛ ا وحدة حيوانية ) & \\
\hline & $0 .,$. & $11 \mathrm{~V}$ & متوسطة ( ؛ 1 - צr وحدة حيوانية) & \\
\hline & $9, \xi$ & rr & كبيرة ( أكثر من جr وحدة حيوانية) & \\
\hline & $1 \cdots$ & $r r \leq$ & الإجمالى & \\
\hline \multirow{5}{*}{ 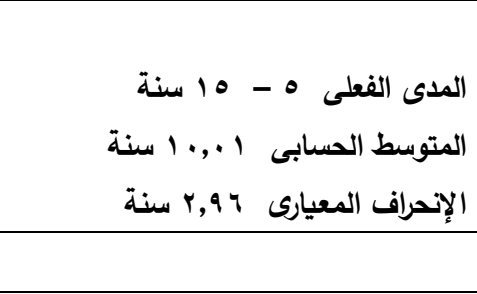 } & & & الخبرة فى تربية الحيوانات: & 。 \\
\hline & $\mid v, 1$ & ؛. & منخفضة ( أقل من ^ مننوات ) & \\
\hline & $\Delta v, r$ & $\mid r \leq$ & متوسطة ( 1 - r سنة ) & \\
\hline & $r 0, r$ & 7. & كبيرة ( أكثر من r I سنة ) & \\
\hline & $1 \cdots$ & $r r \leq$ & الإجمالى & \\
\hline \multirow{5}{*}{ 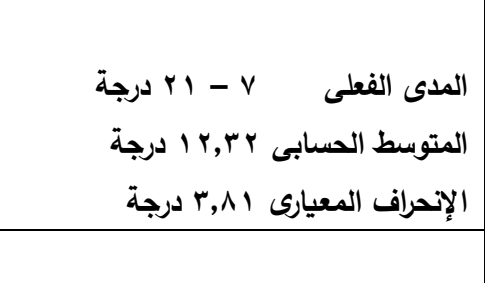 } & & & درجة الإتصال البيطرى: & 7 \\
\hline & or, I & irr & منخفضة ( أقل من r I درجة ) & \\
\hline & $r, r$ & vr & متوسطة ( r - 14 ( درجة ) & \\
\hline & $17, r$ & rs & كبيرة ( أكثر من 17 درجة ) & \\
\hline & $1 \ldots$ & $r r \leq$ & الإجمالى & \\
\hline
\end{tabular}


Sh. A. M. El Tantawy, et al.,

تابع جدول رقم (r): توزيع مربى الأبقار المبحوثين وفقاً لخصائصهم المميزة

\begin{tabular}{|c|c|c|c|c|}
\hline ملاحظات & $\%$ & العدد & الخصائص & b \\
\hline & & & 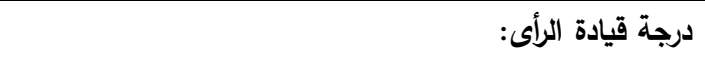 & $v$ \\
\hline 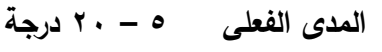 & $r \cdot, l$ & $\leqslant V$ & منخفضة أقل من ا درجات ) & \\
\hline 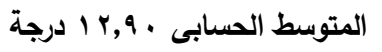 & 00,1 & $1 \times 9$ & متوسطة ( • ( - 1 د درجة ) & \\
\hline \multirow[t]{2}{*}{ الإحراف المعيارى ه .,؛؛ درجة } & $r \leqslant, \wedge$ & $\Delta \wedge$ & كبيرة ( أكثر من ه 1 درجة ) & \\
\hline & $1 \ldots$ & $r r \leq$ & 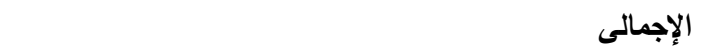 & \\
\hline & & & درجة توافر الذدمات البيطرية للوقاية من مرض الجلد العقدى: & $\wedge$ \\
\hline المدى الفعلى - ب ا درجة & $\varepsilon \wedge, r$ & $11 r$ & غير متوفرة أقل من V درجات ) & \\
\hline المتوسط الحسابى Y V,Y درجة & $\{1, \leqslant$ & $9 \vee$ & متوفرة لحد ما ( v - 9 درجات ) & \\
\hline \multirow[t]{2}{*}{ الإحراف المعيارى I, ب درجة } & $1 \cdot, r$ & $r \varepsilon$ & ( أكثر من 9 درجات ) & \\
\hline & $1 \ldots$ & rrs & الإجمالى & \\
\hline & & & درجة الإستعداد للتغيير: & 9 \\
\hline المدى الفعلى V - V ا درجة & or,. & $\operatorname{lr} \leq$ & منخفضة ( أقل من r I درجة ) & \\
\hline 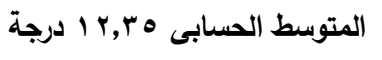 & $r \varepsilon, \uparrow$ & $\wedge 1$ & متوسطة ( r I - 1 ( درجة ) & \\
\hline \multirow{2}{*}{ الإنحراف المعيارى r,v9 درجة } & $\mid r, \varepsilon$ & rq & كبيرة ( أكثر من 17 درجة ) & \\
\hline & $1 \ldots$ & $r r \leq$ & الإجمالى & \\
\hline & & & درجة المرونه الذهنية: & 1. \\
\hline المدى الفعلى ^ - ؛ ؟ درجة & rq,० & 79 & منخفضة ( أقل من س با درجة ) & \\
\hline المتوسط الحسابى 0,09 1 درجة & $\leq 0, V$ & $1 \cdot v$ & متوسطة ( r ا - 19 درجة ) & \\
\hline \multirow{2}{*}{ الإنحراف المعيارى §^,؛ درجة } & $r \varepsilon, \wedge$ & $0 \wedge$ & كبيرة ( أكثر من 9 ( درجة ) & \\
\hline & $1 \ldots$ & rTs & الإجمالى & \\
\hline & & & درجة التأثر بالجيران: & 11 \\
\hline العدى الفعلى V - ا ب درجة & iv,. & $\varepsilon$ & منخفضة ( أقل من Y I درجة ) & \\
\hline المتوسط الحسابى VV, l 1 درجة & $r v, \cdot$ & r4 & متوسطة ( r I - 17 درجة ) & \\
\hline \multirow[t]{2}{*}{ الإحمراف المعيارى · • r, درجة } & $09, \cdot$ & $|r|$ & كبيرة ( أكثر من 17 درجة ) & \\
\hline & $1 \cdots$ & $r r \leq$ & الإجمالى & \\
\hline & & & درجة المعرفة بأعراض الإصابة بمرض الجلد العقدى: & ir \\
\hline الددى الفعلى 10 - • · درجة & $0 ., \varepsilon$ & 111 & منخفضة أقل من ·r درجة ) & \\
\hline المتوسط الحسابى \, Y, درجة & rr, & v^ & متوسطة ( •r - مץ درجة ) & \\
\hline \multirow[t]{2}{*}{ الإنحراف المعيارى 1.,_ء درجة } & $17, r$ & rs & كبيرة ( أكثر من 0Y درجة ) & \\
\hline & $1 \ldots$ & $r r \varepsilon$ & الإجمالى & \\
\hline & & & درجة المعرفة بأسباب الإصابة بمرض الجلد العقدى: & ir \\
\hline المدى الفعلى ب - ب ا درجة & $r, r$ & or & منخفضة (أقل من ^ درجات ) & \\
\hline المتوسط الحسابى \ 9, درجة & $\leq 7, r$ & $1 \cdot 1$ & متوسطة ( ^ - · ( درجات ) & \\
\hline الإنحراف المعيارى 90, إرجة & $r, T$ & $v \varepsilon$ & كبيرة ( أكثر من · ( درجات ) & \\
\hline
\end{tabular}

المصدر: إستمارات الإستبيان 
جدول رقم (ץ): توزيع مربى الأبقار المبحوثين وفقاً لمستوى تبنيهم للتوصيات الإرشادية للوقاية من مرض الجلد العقدى.

\begin{tabular}{|c|c|c|c|c|}
\hline الإحمراف المعيارى & المتوسط الحسابى & $\%$ & عدد & فئات مستوى التبنى \\
\hline \multirow{4}{*}{ ا וף,؛ درجة } & \multirow{4}{*}{ 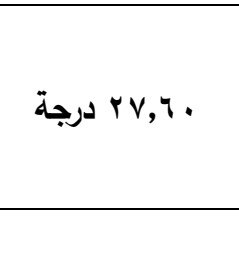 } & or,. & $1 r \leq$ & منخفض (أقل من rV درجة) \\
\hline & & rq,. & 91 & متوسط ( - r - د درجة ) \\
\hline & & $\wedge, \cdot$ & 19 & مرتفع (أكبر من س د درجة) \\
\hline & & $1 \ldots$ & 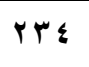 & الإجمالى \\
\hline
\end{tabular}

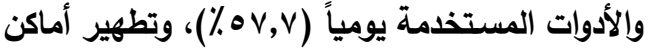

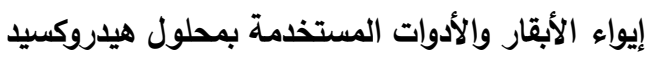

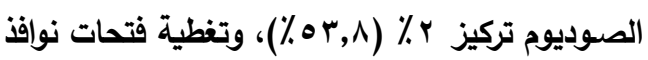

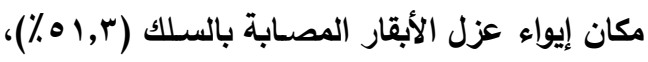

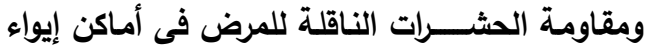

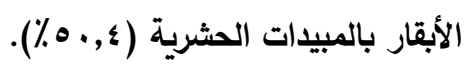
r- المسـتوى الثالث (معدل تطبيق منخفض) ويتضــمن التوصسيات التسـع المتبقية التى أقر بصـحة كل منها

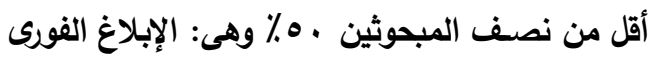
للطب الوقائى عند ظهور الإصابة بالمرض في الأبـ الأبقار

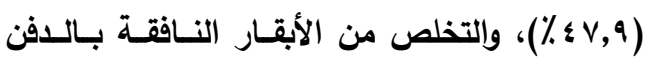

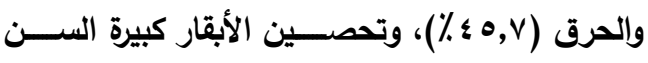

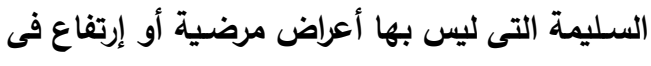

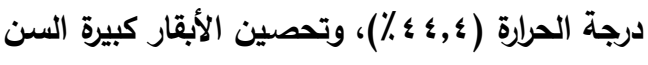

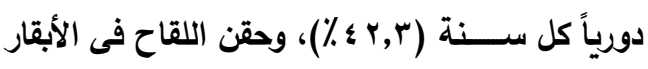

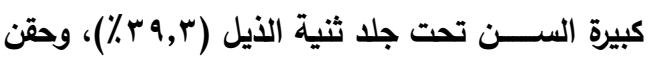

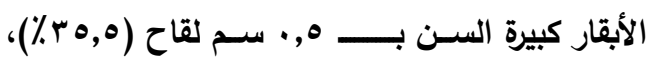

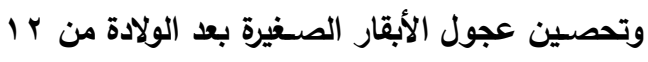

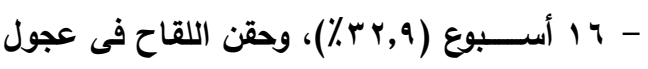

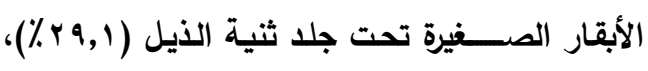

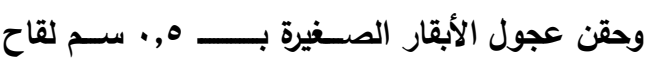
. $(\% r, 0)$

ويتضــح مما سـبق عرضــهـ أن أكثر من ثلاثة أرباع التوصيات الإرشادية للوقاية من مرض الجلد العقدى (1)

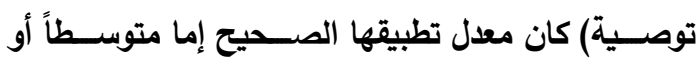
منخفضاً من جانب مربى الأبقار المبحوثين، ويمكن إرجاع
ثانياً: معدل التطبيق الصحيح لمربى الأبقار المبحوثين لكل توصية من التوصيات الإرشادية للوقاية

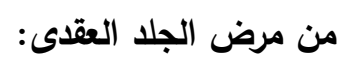

وفيما يتعلق بمعدلات التطبيق الصحيح لمربى الأبقار

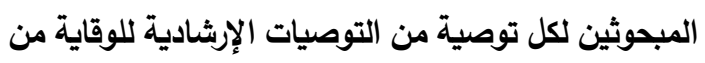
مرض الجلد العقدى الثمانى عشرة موضوع البحث والتى لتى الإنى

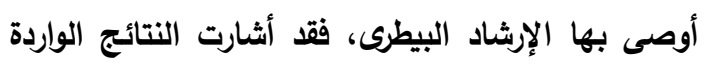

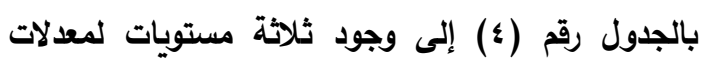

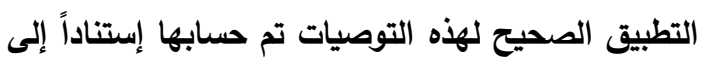
معدل التطبيق الصحيح المشار إليه آنفاً بالطريقة البحثية كالتالى:

1- المسـتوى الأول (معدل تطبيق مرتفع) ويتضـمن أربع

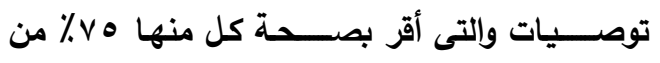

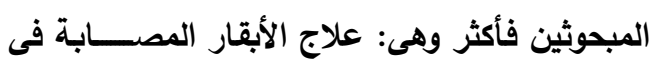

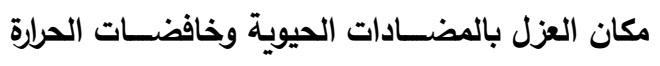

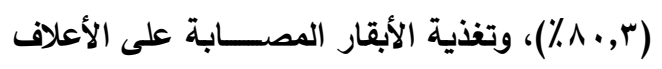

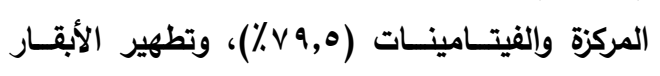

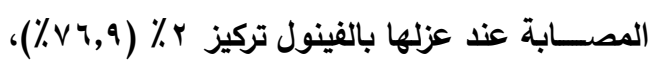

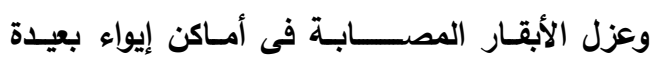
. (\%०, r) r- المسـتوى الثانى (معدل تطبيق متوســط) ويتضــــن

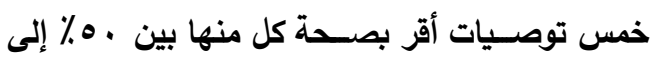
أقل من ه ٪\% من المبحوثين وهى: وضـــــع الأبقار

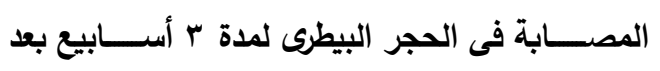

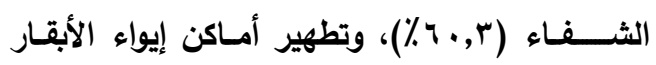


Sh. A. M. El Tantawy, et al.,

حين ما يزيد عن نصـفهم ؛ ,. ه ٪ جاءت درجة معرفتهم

بأسباب الإصابة بمرض الجلد العقدى منخفضة. الأمر الذى يتطلب من جـانب القائمين على العمل الإششـادى الزراعى بذل مزيد من الجها لســ هذا النقص النص فى مستوى تبنى مربى الأبقار لتلك التوصيات، وذلك من التن خلال تخطيط وتنفيذ برامج إرشــــادية مســتقبلية بهـف تدريبهر من خلال الإيضاحات العملية على كيفية التطبيق

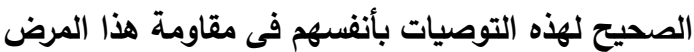

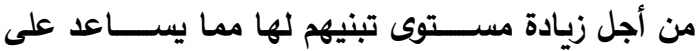
النهوض بقطاع الثروة الحيوانية.
ذلك إلى أن ما يزيد عن نصـــف المبحوثين \%, 1 ه من

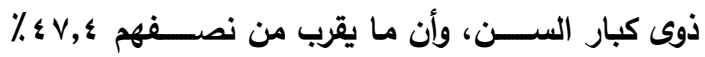

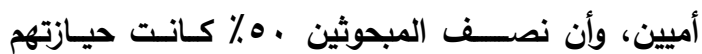

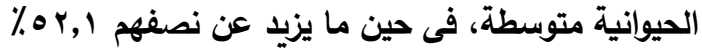
جاءت درجة إتصــالهم البيطرى منخفضــة، وأن ما يقرب لمان

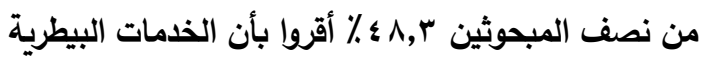

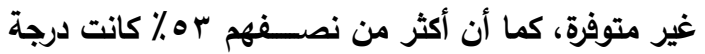
إســـتعدادهم للتغيير منخفضــــة، وأن ما يقرب من ثلثى فئى المبحوثين ه ٪ جاءت درجة تأثرهم بالجيران مرتفعة، فى

جدول رقم (؛): توزيع مربى الأبقار المبحوثين وفقاً لمعدل تطبيقهم الصحيح لكل توصية من التوصيات الإرشادية للوقاية

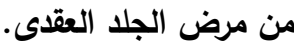

\begin{tabular}{|c|c|c|c|c|c|}
\hline \multicolumn{2}{|c|}{ 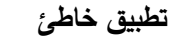 } & \multicolumn{2}{|c|}{ تطبيق صحيح } & \multirow[t]{2}{*}{ 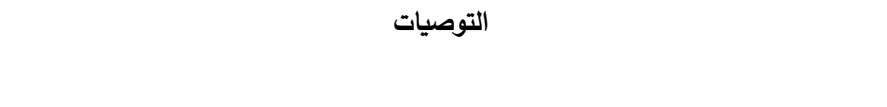 } & \multirow[t]{2}{*}{ م } \\
\hline$\%$ & 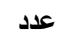 & $\%$ & 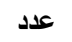 & & \\
\hline 00,7 & ir. & $\leqslant \leqslant, \varepsilon$ & $1 \cdot \varepsilon$ & تحصين الأبقار كبيرة السن السليمة التى ليس بها أعراض مرضية أو إرتفاع فى درجة & 1 \\
\hline $7 \leqslant, 0$ & 101 & $r_{0,0}$ & $\Lambda r$ & حقن الأبقار كبيرة السن بـ •, · سم لقاح & r \\
\hline $7 \cdot, \mathrm{V}$ & $1 \leq r$ & rq,r & ar & حقن اللقاح فى الأبقار كبيرة السن تحت جلد ثنية الذيل & $r$ \\
\hline $7 v, 1$ & $10 \mathrm{~V}$ & $r r, q$ & $\vee \vee$ & تحصين عجول الأبقار الصغيرة بعد الولادة من r | - 1 أسبوع & $\varepsilon$ \\
\hline$v 7,0$ & 189 & $r r, 0$ & 00 & حقن عجول الأبقار الصغيرة بـ ه, · سم لقاح & $\bullet$ \\
\hline$v \cdot, q$ & 197 & rq, & $\uparrow \wedge$ & حقن اللقاح فى عجول الأبقار الصغيرة تحت جلد ثنية الذيل & 9 \\
\hline$\Delta v, v$ & itso & $\varepsilon r, r$ & 99 & تحصين الأبقار كبيرة السن دورياً كل سنة & $v$ \\
\hline or, 1 & Irr & $\leq \vee, q$ & $11 \mathrm{r}$ & الإبلاغ الفورى للطب الوقائى عند ظهور الإصابة بالمرض فى الأبقار & $\wedge$ \\
\hline $0 \leqslant, \Gamma$ & irv & $\varepsilon 0, V$ & $1 \cdot v$ & التخلص من الأبقار النافقة بالدفن والحرق & 9 \\
\hline$r \leqslant, \wedge$ & $\bullet \wedge$ & vo,r & $1 \times 4$ & عزل الأبقار المصابة فى أماكن إيواء بعيدة & 1. \\
\hline$r r, 1$ & $0 \leqslant$ & $v 4,9$ & 11 & تطهير الأبقار المصابة عذ عزلها بالفينول تركيز r\% & 11 \\
\hline $19, \mathrm{~V}$ & $\leqslant ५$ & $\Lambda \cdot, r$ & 111 & علاج الأبقار المصابة فى مكان العزل بالمضادات الحيوية وخافضات الحرارة & ir \\
\hline$\varepsilon \wedge, \vee$ & $11 \varepsilon$ & $01, r$ & ir. & تفطية فتحات نوافذ مكان إيواء عزل الأبقار المصابة بالسلك & ir \\
\hline$\leq 4, r$ & $1 \cdot 1$ & or, $\Lambda$ & Iry & تطهير أماكن إيواء الأبقار والأدوات المستخدمة بمحلول هيدروكسيد الصوديوم تركيز r٪ & $1 \leqslant$ \\
\hline$\leq r, r$ & 99 & $\bullet \vee, v$ & iro & تطهير أماكن إيواء الأبقار والأدوات المستخدمة يومياً & 10 \\
\hline$\leqslant 9,7$ & 117 & $0 ., \varepsilon$ & 111 & مقاومة الحشرات الناقلة للمرض فى أماكن إيواء الأبقار بالمبيدات الحشرية & 17 \\
\hline$r \cdot, 0$ & $\varepsilon \wedge$ & $\vee ৭, 0$ & $1 \wedge 7$ & تغذية الأبقار المصابة على الأعلاف المركزة والفيتامينات & iv \\
\hline rq, $\vee$ & $9 r$ & $7 \cdot r$ & $1 \leq 1$ & وضع الأبقار المصابة فى الحجر البيطرى لمدة r أسابيع بعد الثفاء & 11 \\
\hline
\end{tabular}


الأولى، يليهم الأهل والجيران، ثم الخبرة الثخصية، يليها

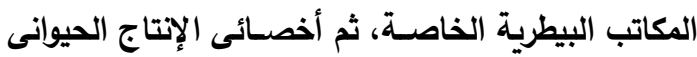

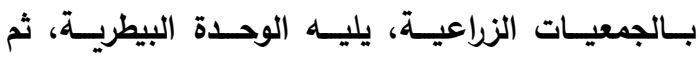
المتخصــــــــون بمحطـة البحوث الزراعيـة، يليهم

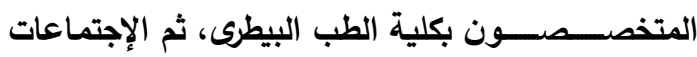
والندوات الإرشسادية، يليها المجلات والنشرات الإرشـادية،

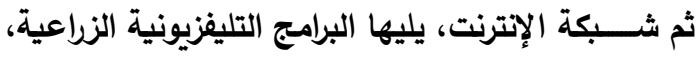
وأخيراً البرامج الإذاعية الزراعية.
ثالثاً: مصادر المعلومات التى يستمد منها مربى الأبقار المبحوثين معارفهم عن التوصيات الإرشادية للوقاية من مرض الجلد العقدى:

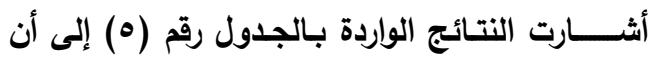

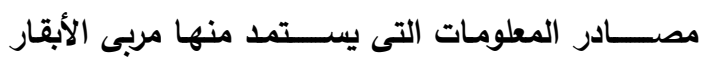

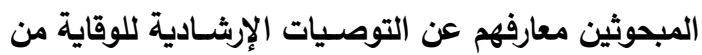
مرض الجلد العقدى جـاءت مرتبـة تنـازليـاً على النحو

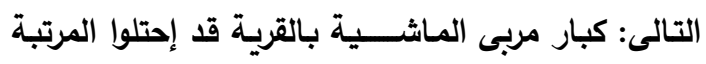

جدول رقم (ه): ترتيب مصادر المعلومات التى يستمد منها مربى الأبقار المبحوثين معارفهم عن التوصيات الإشثادية للوقاية

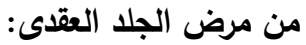

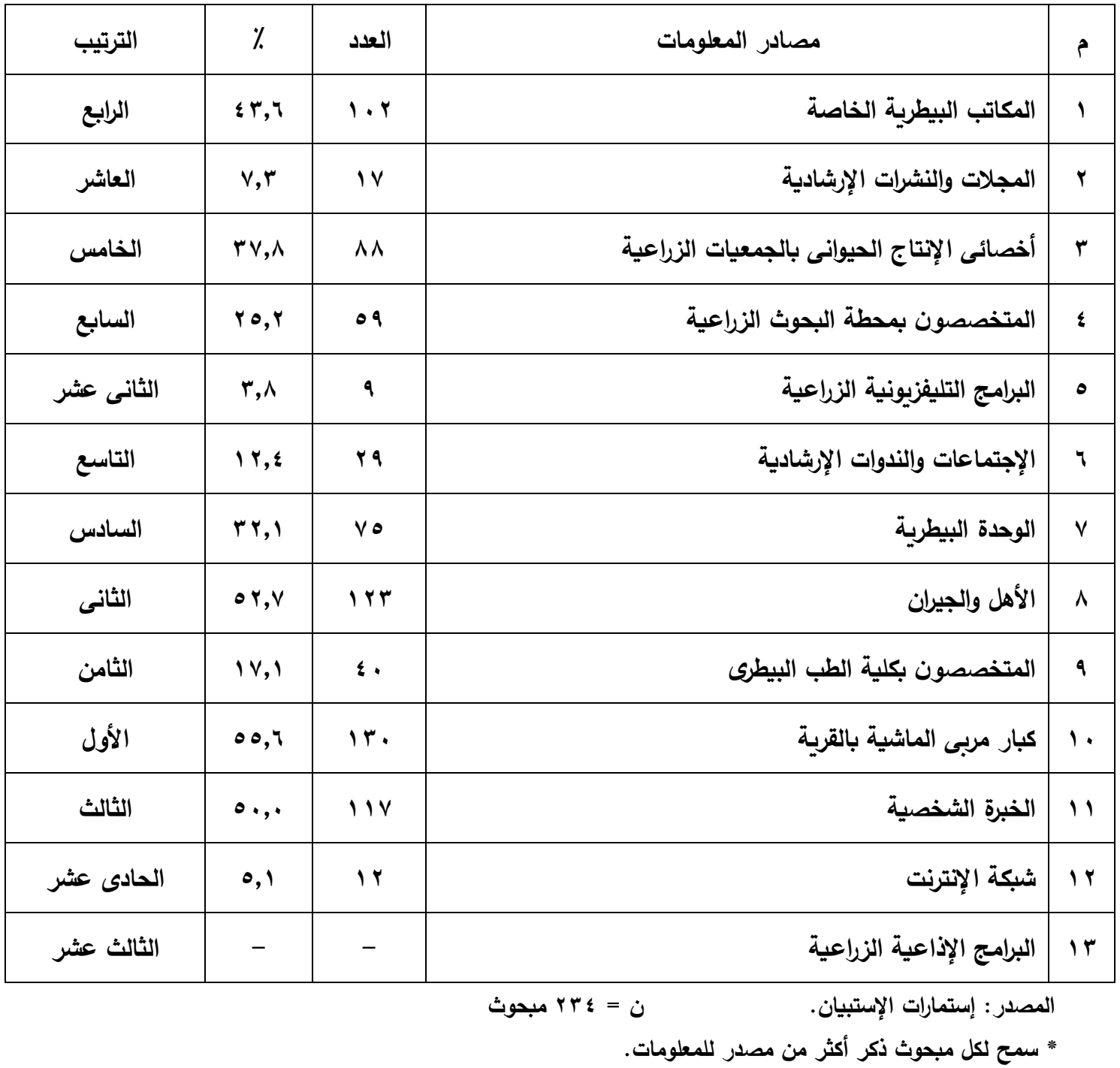


مما قد يتطلب ضرورة إهتمام كافة الأجهزة المعنية

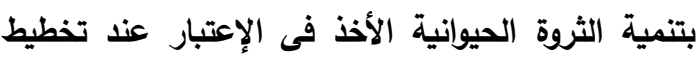
وتنفيذ برامج إرثادية تستهدف نشر التوصيات الإرشادية للوقاية من مرض الجلد العقدى بين مربى الأبقار حتى الأسي

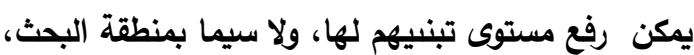
أو مناطق آخرى بالجمهورية.

رابعاً: العلاقة الإرتباطية بين درجة تبنى مربى الأبقار

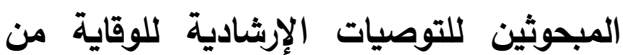
مرض الجلد العقدى والمتغيرات المستقلة

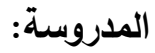

للتعرف على المتغيرات المستقلة المدروسـة المرتبطة معنوياً بدرجة تبنى مربى الأبقار المبحوثين للتوصــيات الإرشــادية للوقاية من مرض الجلد العقدى كمتغير تابع،

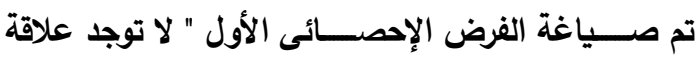
إرتباطية معنوية بين بدرجة تبنى مربى الأبقار المبحوثين للتوصيات الإرشادية للوقاية من مرض الجلد العقدى وكل

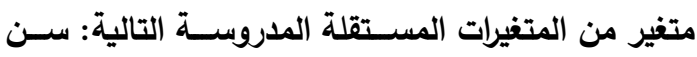

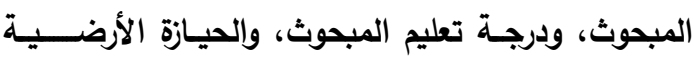
الزراعية، والحيازة الحيوانية المزرعية، والخبرة فى تربية الحيوانات، ودرجة الإتصسال البيطرى، ودرجة قيادة الرأى،

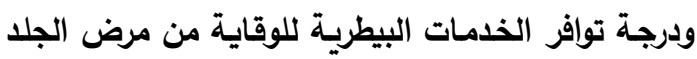

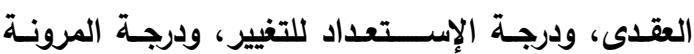

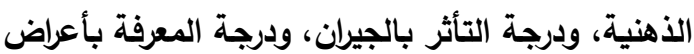

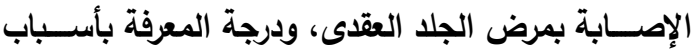
الإصابة بمرض الجلد العقدى ".

ولإختبار صـحة هذا الفرض أسـتخدم معامل الإرتباط البسـيط لبيرسـون، حيث أثـارت النتائج الواردة بالجدول

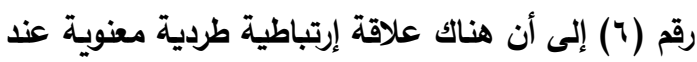

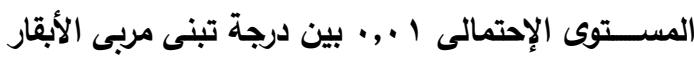
المبحوثين للتوصسيات الإرشسادية للوقاية من مرض الجلد العقدى وبين كل متغير من المتغيرات المستقلة المدروسة التالية: درجة تعليم المبحوث، وإلحيازة الأرضية الزراعية،
ومن النتائج السـابقة يتضح سيادة مصسادر معلومات مربى الأبقار المبحوثين غير الرسمية (غير المتخصصة لئية مثل: كبار مربى الماشية بالقرية، والأهل والجيران، والخبرة

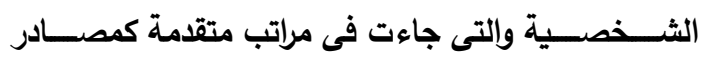

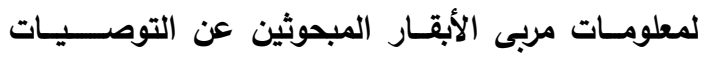
الإرشسادية للوقاية من مرض الجلد العقدى، وقد يعزى ذلك الكئ

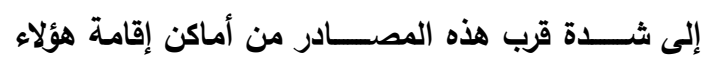

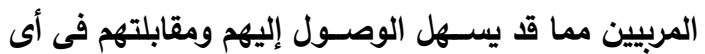

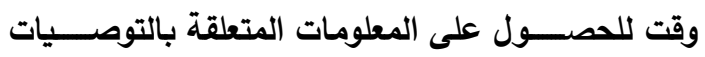
الإرشـادية للوقاية من هذا المرض، الأمر الذى يجعل هذه الذهات

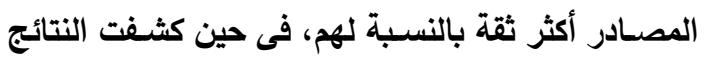

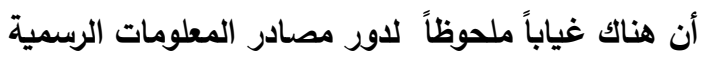

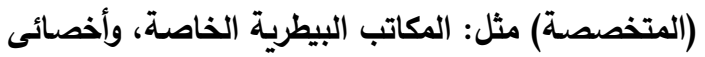

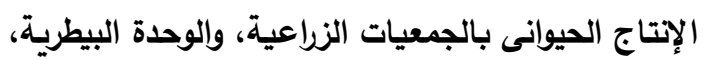
والمتخصصون بحطة البحوث الزراعية، والمتخصصون بكلية الطب البيطرى، والإجتماعات والندوات الإرشـــادية، والمجلات والنثــــرات الإرشـــادية، والبرامج التليفزيونية

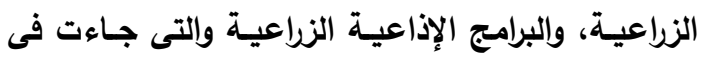

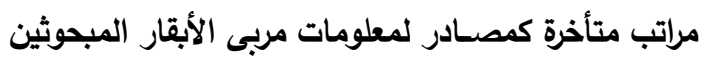
عن التوصيات الإرشادية للوقاية من مرض الجلد العقدى،

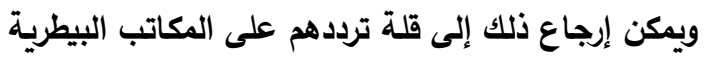

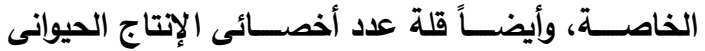

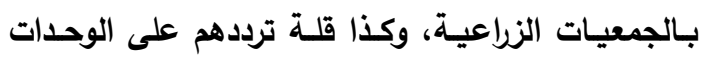
البيطرية، ومحطة البحوث الزراعية، وكلية الطب البيطرى،

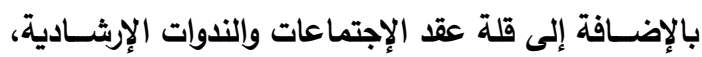

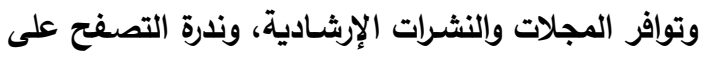

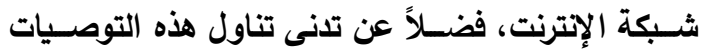

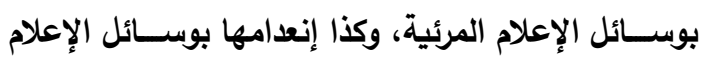
المسموعة، مما قد جعل عدم ثقة مربى الأبقار بهم، ومن الإندان

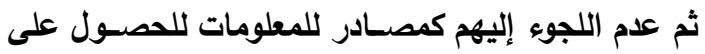

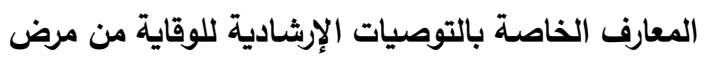

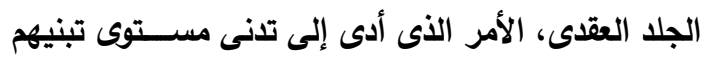

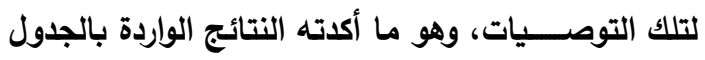

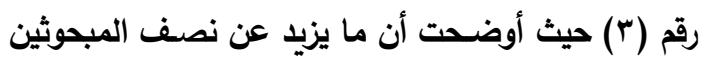

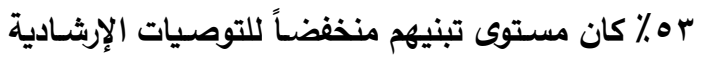
للوقاية من مرض الجلد العقدى بمنطقة البحث. 
بمرض الجلد العقدى، كلما توقع زيـادة إهتمامهم وتبنيهم للتوصسيات الإرشـادية للوقاية من هذا المرض، مما يؤدى لهري إلى النهوض بـالثروة الحيوانيـة. فى حين وجدت علاقة إرتباطية عكسية معنوية عند المسـتوى الإحتمالى الـ ل,., بين المتغير التابع وكل من: سـن المبحوث، ودرجة التأثر

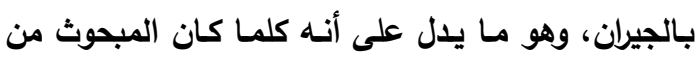

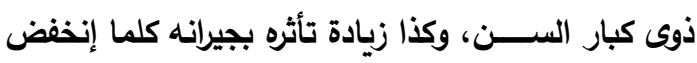

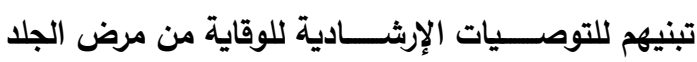
العقدى، الأمر الذى ربما يؤدى إلى عزوفه عن تبنى تلك

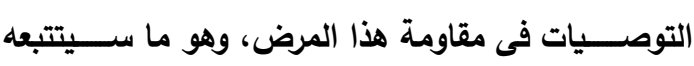

حدوث خسائر إقتصادية كبيرة بقطاع الثروة الحيوانية. وبنـاءاً عليه أمكن رفض الفرض الإحصــــائى الأول

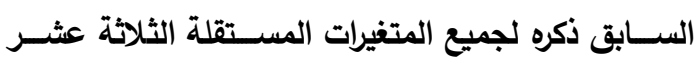

موضع البحث.
والحيازة الحيوانية المزرعية، والخبرة فى تربية الحيوانات، ودرجة الإتصال البيطرى، ودرجة قيادة الرأى، ودرجة توافر الخدمات البيطريـة للوقاية من مرض الجلد العقدى، ودرجة الإســـتعداد للتغيير، ودرجـة المرونـة الـذهنيـة، ودرجـة المعرفة بأعراض الإصـــابة بمرض الجلد العقدى، ودرجة ودرة

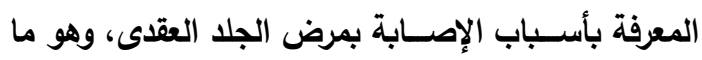
يعنى تحرك المتغير التابع وكل متغير من هذه المتغيرات

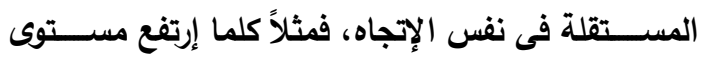

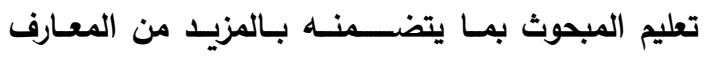

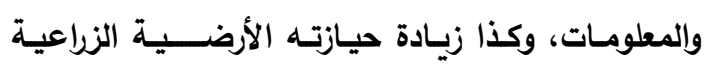
والحيوانية، وإرتفاع مســـتوى خبرته فى تربية الحيوانات، وكية وكثرة إتصــــاله البيطرى، وقيادته للرأى أكثر من غيره فى

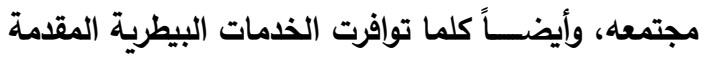

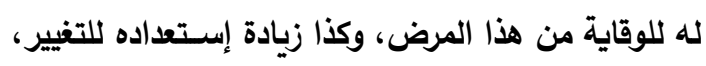

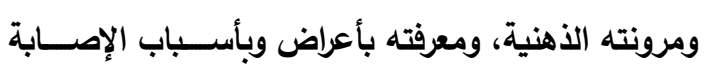

جدول رقم (†): قيم معاملات الإرتباط البسيط بين درجة تبنى مربى الأبقار المبحوثين للتوصيات الإرشادية للوقاية من مرض الجلد العقدى والمتغيرات المستقلة المدروسة.

\begin{tabular}{|c|c|c|}
\hline قيم معاملات الإرتباط البسيط & المتغيرات المستقلة & b \\
\hline$* * \varepsilon, r-$ & سن المبحوث & 1 \\
\hline$* * \leqslant r q$ & درجة تعليم المبحوث & r \\
\hline$* *$ * 9 & الحيازة الأرضية الزراعية & $r$ \\
\hline$* * \varepsilon 10$ & الحيازة الحيوانية المزرعية & $\varepsilon$ \\
\hline$* * \varepsilon, 0$ & الخبرة فى تربية الحيوانات & 0 \\
\hline$* * \varepsilon i r$ & درجة الإتصال البيطرى & 7 \\
\hline$* * \varepsilon \cdot r$ & درجة قيادة الرأى & V \\
\hline$* * \varepsilon \cdot 9$ & درجة توافر الخدمات البيطرية للوقاية من مرض الجلد العقدى & $\wedge$ \\
\hline$* * \varepsilon Y \curlyvee$ & درجة الإستعداد للتغيير & 9 \\
\hline$* * \varepsilon 11$ & درجة المرونة الذهنية & $1 \cdot$ \\
\hline$* * \varepsilon \cdot \Lambda-$ & درجة التأثر بالجيران & 11 \\
\hline$* * \varepsilon Y$ & درجة المعرفة بأعراض الإصابة بمرض الجلد العقدى & Ir \\
\hline$* * \varepsilon \ldots$ & درجة المعرفة بأسباب الإصابة بمرض الجلد العقدى & ir \\
\hline
\end{tabular}


الحادث فى درجة تبنى مربى الأبقار المبحوثين للتوصيات

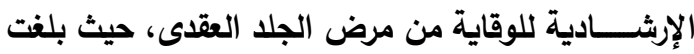

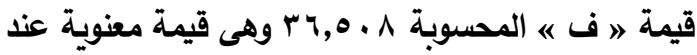

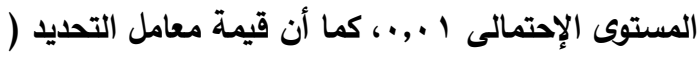
( R'

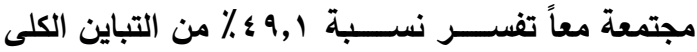
الحادث فى درجة تبنى مربى الأبقار المبحوثين للتوصيات الإرشادية للوقاية من مرض الجلد العقدى، وهذه المتغيرات

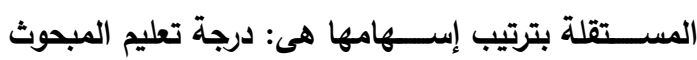

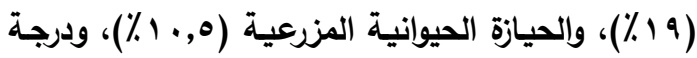
المعرفة بأعراض الإصسابة بمرض الجلد العقدى (Y,Y.\%)،

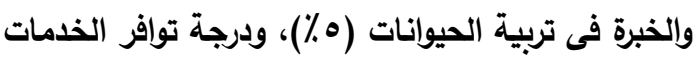

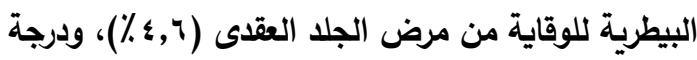
الإتصال البيطرى (^,^ץ\%).

وبذلك أمكن رفض الفرض الإحصــــائى الثانى فيما يتعلق بالمتغيرات الســـة الســـابق ذكرها، بينما لم يمكن رفضه بالنسبة لباقى المتغيرات المستقلة الأخرى.
خامسـاً: إسـهام المتغيرات المسـتقلة المدروسـة ذات العلاقة الإرتباطيـة المعنويـة فى تفســير التباين الكلى الحادث فى درجة تبنى مربى الاربـ اطبه

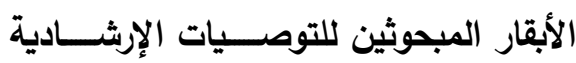
للوقاية من مرض الجلد العقدى: لتحديد نسبة إسهام كل متغير من المتغيرات المستقلة ذات العلاقات الإرتباطية المعنوية فى تفسير التباين الكلى الحادث فى درجة تبنى مربى الأبقار المبحوثين للتوصيات

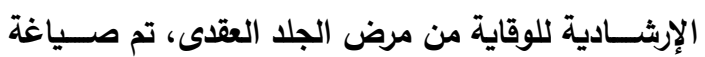

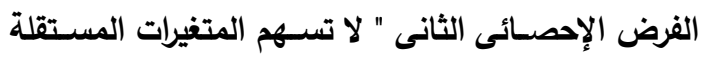
ذات العلاقة الإرتباطية المعنوية بلرجة تبنى مربى الأبقار المبحوثين للتوصسيات الإرشسادية للوقاية من مرض الجلد

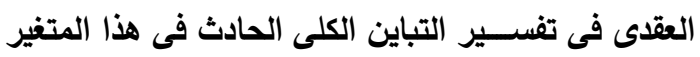

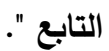
ولإختبار صــة هذا الفرض أســتخدم نموذج التحليل الإرتباطى والإحدارى المتعدد المتدرج الصاعد، حيث بينت النتائج الواردة بالجدول رقم (V) أن ستة متغيرات مستقلة

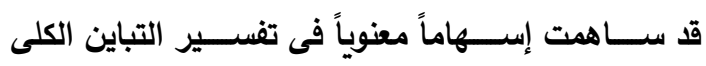

جدول رقم (V): نتائج التحليل الإرتباطى والإحدارى المتعدد المتدرج الصاعد بين درجة تبنى مربى الأبقار المبحوثين للتوصيات الإرشادية للوقاية من مرض الجلد العقدى والمتغيرات المستقلة المدروسة.

\begin{tabular}{|c|c|c|c|c|c|}
\hline اللمائولية النسبة & التلتباين النسبة & قيمة " ت " & الإنحدار & المتغير الداخل فى التحليل & b \\
\hline 19, &., 19 & $* * r, \leqslant r r$ & $\cdot, .0 \leq$ & درجة تعليم المبحوث & 1 \\
\hline $1 ., 0$ & $\cdot, r 90$ & $* * \leq, V Y 1$ & די & الحيازة الحيوانية المزرعية & $r$ \\
\hline$v, r$ & • & $* *$ ห,१чะ &., .04 & درجة المعرفة بأعراض الإصابة بمرض الجلد العقدى & $r$ \\
\hline$\bullet, \cdot$ &.,$\leqslant 1 \vee$ & $* * \leq, r \wedge r$ &., $1 \leqslant \leqslant$ & الخبرة فى تربية الحيوانات & $\varepsilon$ \\
\hline ؟, & 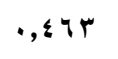 & $* * \leq, \cdot \wedge \leq$ &., $1 \leqslant r$ & درجة توافر الخدمات البيطرية للوقاية من مرض الجلد العقدى & $\bullet$ \\
\hline$r, \Lambda$ & $\cdot, \leqslant 91$ & $* * r, 0 \leq q$ &., 4 & درجة الإتصال البيطرى & 9 \\
\hline
\end{tabular}




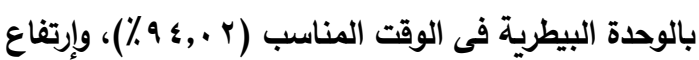

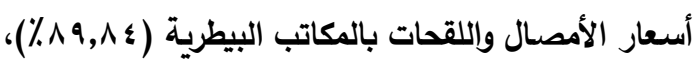

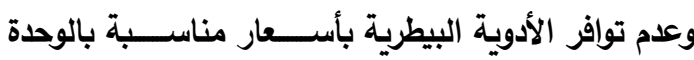

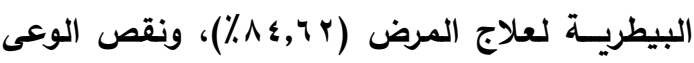

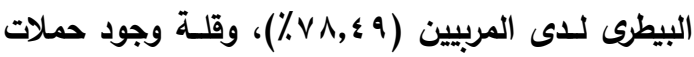

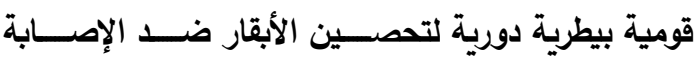

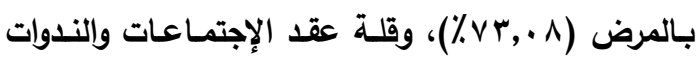

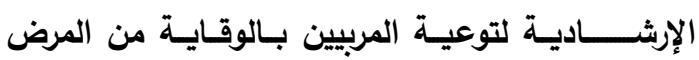

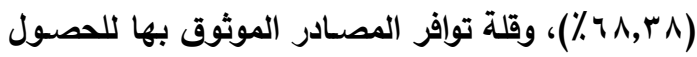

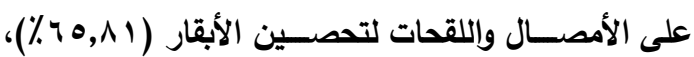

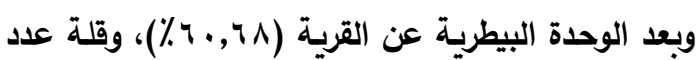

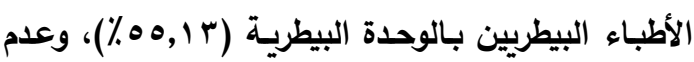

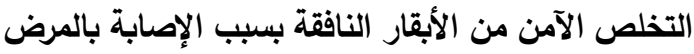
(•ه \%)، وعدم توافر أماكن للحجر البيطرى لعزل الأبقار

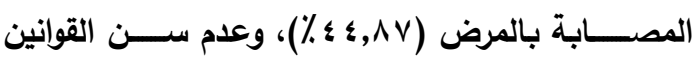

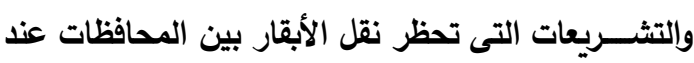

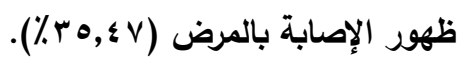

ومما سـبق يتضـح بضـرورة أخذ متغيرات درجة تعليم المبحوث، وإلحيازة الحيوانيـة المزرعية، ودرجـة المعرفة فئة بأعراض الإصسابة بمرض الجلد العقدى، والخبرة فى تربية

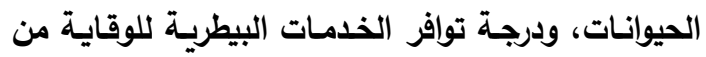
مرض الجلد العقدى، ودرجة الإتصال البيطرى فى الإعتبار

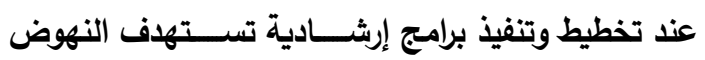
بالإنتاج الحيوانى بمنطقة البحث فى محافظة الغربية لما

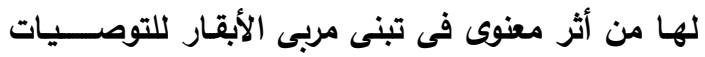
الإرشادية للوقاية من مرض الجلد العقدى.

سادساً: المعوقات التى تواجه مربى الأبقار المبحوثين

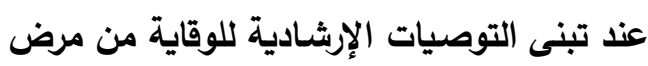
الجلد العقدى من وجهة نظرهم:

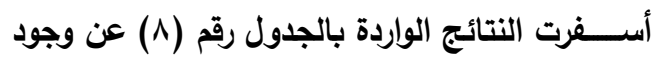

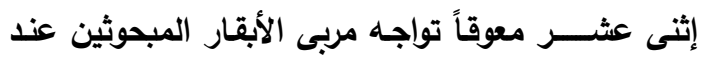

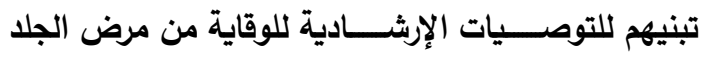

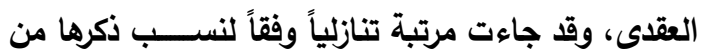

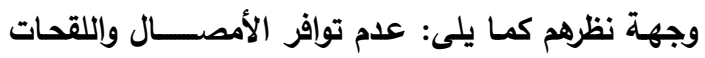

جدول رقم (^): المعوقات التى تواجه مربى الأبقار المبحوثين عند تبنى التوصــيات الإرثـــادية للوقاية من مرض الجلد

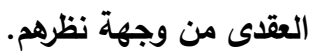

\begin{tabular}{|c|c|c|c|}
\hline$\%$ & 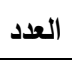 & 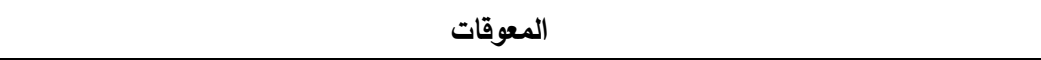 & a \\
\hline $9 \varepsilon, \cdot r$ & rr. & عدم توافر الأمصال وإللقحات بالوحدة البيطرية فى الوقت المناسب & 1 \\
\hline$\wedge q, \vee \leq$ & i. & إرتفاع أسعار الأمصال واللقحات بالمكاتب البيطرية & r \\
\hline$\Lambda \varepsilon, T r$ & 191 & عدم توافر الأدوية البيطرية بأسعار مناسبة بالوحدة البيطرية لعلاج المرض & r \\
\hline$\vee ৭, \leqslant 9$ & 114 & نقص الوعى البيطرى لاى المربيين & $\varepsilon$ \\
\hline$v r, \cdot \Lambda$ & $|v|$ & قلة وجود حملات قومية بيطرية دورية لتحصين الأبقار ضد الإصابة بالمرض & $\bullet$ \\
\hline$\uparrow \wedge, \hookleftarrow \wedge$ & 17. & قلة عقد الإجتماعات واللندوات الإرشادية لتوعية المربيين بالوقاية من المرض & 7 \\
\hline $70, \wedge 1$ & $10 \leq$ & قلة توافر المصادر الموثوق بها للحصول على الأمصال واللقحات لتحصين الأبقار & $\checkmark$ \\
\hline $7 \cdot, 14$ & $1 \leqslant r$ & بعد الوحدة البيطرية عن القرية & $\wedge$ \\
\hline $00,1 \mathrm{r}$ & 149 & قلة عدد الأطباء البيطرين بالوحدة البيطرية & 9 \\
\hline$\bullet \cdot, \cdot$ & 118 & عدم التخلص الآمن من الأبقار النافقة بسبب الإصابة بالمرض & 1. \\
\hline$\varepsilon \varepsilon, \wedge \vee$ & 1.0 & عدم توافر أماكن للحجر البيطرى لعزل الأبقار المصابة بالمرض & 11 \\
\hline$r_{0, \Sigma} \leqslant$ & $\wedge r$ & عدم سن القوانين والتشريعات التى تحظر نقل الأبقار بين المحافظات عند ظهور الإصابة بالمرض & ir \\
\hline
\end{tabular}

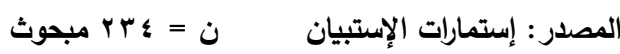


بالتوصيات الإرشادية للوقاية من هذا المرض وتبنيهم

لها.

r- - أوضــــت النتائج قلة وجود حملات قومية بيطرية دورية لتحصين الأبقار ضـد الإصـابة بالمرض، فإنهان

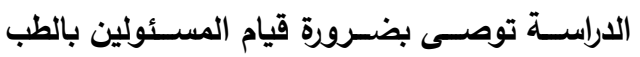
البيطرى بـالحملات القوميـة البيطريـة الـــوريـة والمتنقلة لسـهولة توفير الرعاية الصــية البيطرية للأبقار وذلك فيما يتعلق بالتطعيم، والوقاية والعلاج

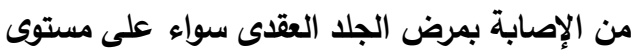
منطقة البحث بصـفة خاصسة، والجمهورية بصـفة الجـة

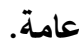
؛ - أسـفرت النتائج عن بعد الوحدة البيطرية عن منطقة

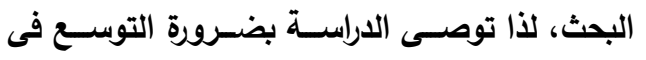

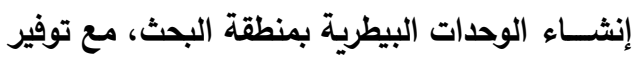

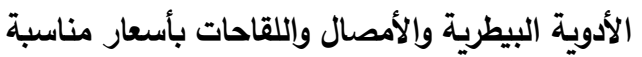
لتطعيم الأبقار ضد الإصابة بمرض الجلد العقدى. كثــفت النتائج عن قلة أعداد الأطباء البيطريين

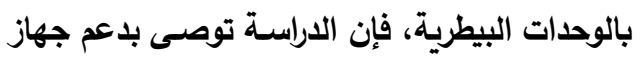

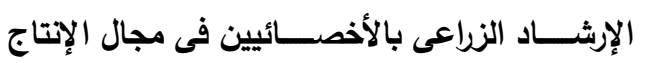
الحيوانى والصـــــة البيطريـة لتوعية مربى الأبقار

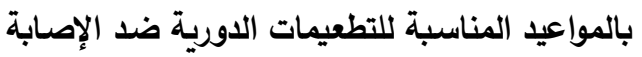

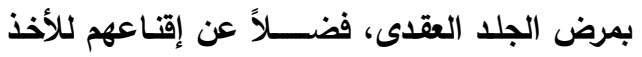
بالتوصيات الإرشادية للوقاية من هذا المرض سواء

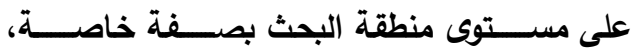
والجمهورية بصفة عامة. ד- أظهرت النتائج عدم توافر أمساكن للحجر البيطرى

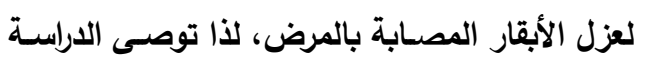

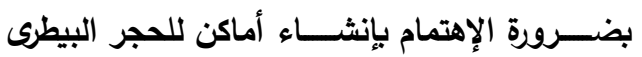
بمنطقة البحث لعزل الأبقار المصــابة بمرض الجلد العقدى حتى يمكن تقليل نسبة إنتشار الإصابة بهذا المرض. - ان أسـفرت النتائج عن عدم سـن القوانين والتشـريعات التى تحظر نقل الأبقار بين المحافظات عند ظهور الإصـابة بالمرض، فإن الدراسـة توصى قيام الأجهزة
الأمر الذى يتطلب بـل المزيـــ من الجهود المكثفة

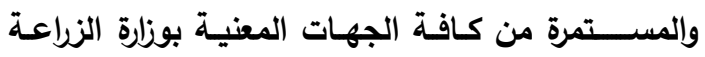

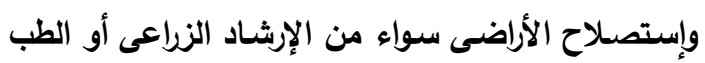

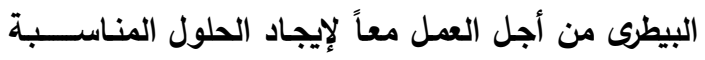

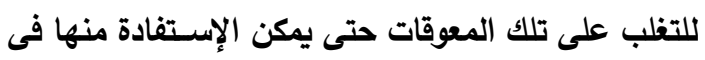

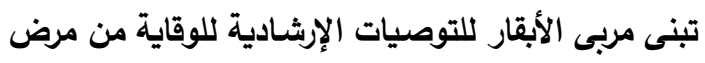

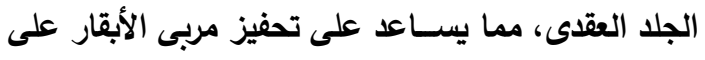

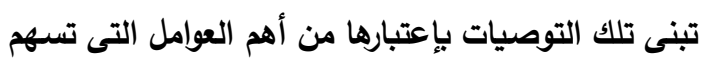
فى الحد من خطورة هذا المرض، ومن ثم تنمية الثروة الحيوانية فى مصر. التوصيات بناءاً على النتائج التى أسفر عنها البحث يوصى بالآتى: 1- أفادت النتائج إنخفاض مســـتوى تبنى مربى الأبقار

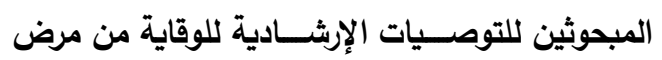
الجلد العقدى، لذا فإن الدراســـة توصـــ بقيام جهاز الإرشاد الزراعى بتخطيط وتنفيذ برامج إرشادية تهاف لإن التهان

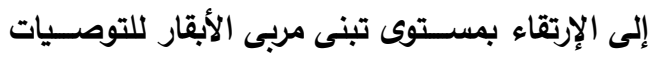

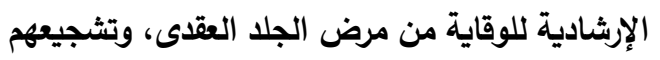

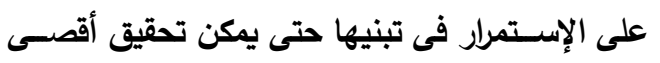

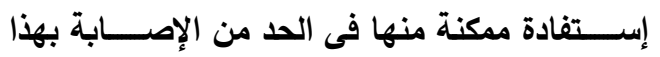
المرض بمنطقة البحث. r- - أثـارت النتائج إلى أن متغيرات درجة تعليم المبحوث،

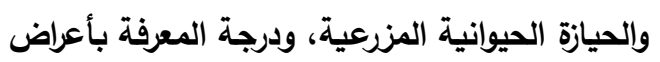

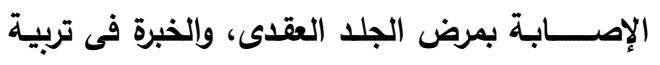

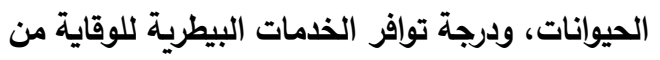
مرض الجلد العقدى، ودرجة الإتصــــال البيطرى كانت

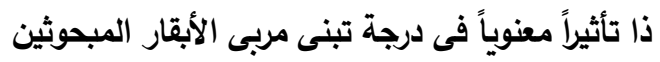

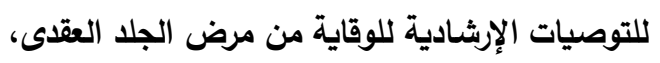

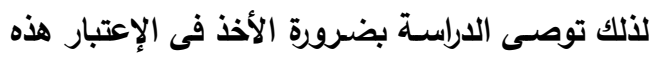

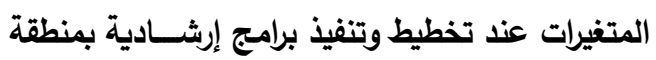
البحث تسـتهف تنمية البنيان المعرفى لمربى الأبقار 
محافظة كفرالثـيخ، رسـالة ماجسـتير، كلية الزراعة بكفرالثيخ، جامعة طنطا.

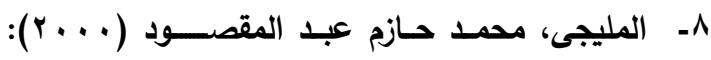
مستوى معرفة وتنفيذ الزراع لممارسـات تربية ورعاية ماثشية اللبن بمحافظة المنوفية، معهد بحوث الإرشاد الزراعى والتنميـة الريفيـة، مركز البحوث الزراعيـة،

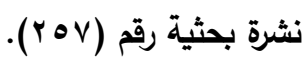

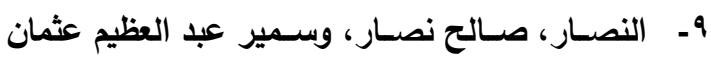

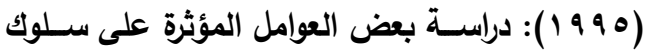
تبنى الزراع لبعض الخبرات الإنتـاجيـة الحيوانيـة

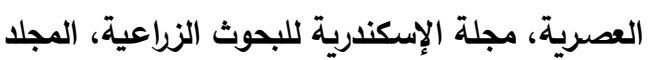
الأربعون، العدد الثالث، سبتمبر.

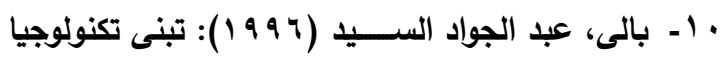
النهوض بـالإتـاج الحيوانى بين مزارعى مركز قلين

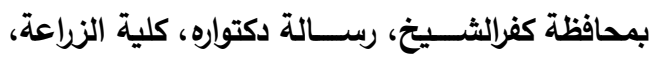
جامعة طنطا.

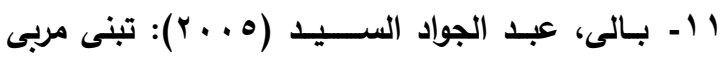
الماشسية لبعض الممارسـات البيطرية، مجلة البحوث

الزراعية، جامعة طنطا، مجلد ( آب)، العدد الرابع.

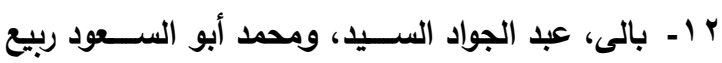

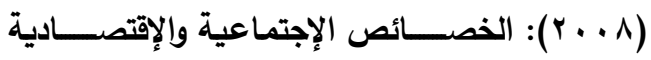

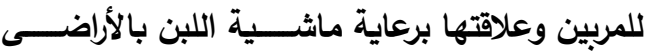
الجديدة بمحافظة كفرالثـيخ، مجلة جامعة المنصسورة للعلوم الزراعية، مجلد بr ، العدد (ع)، إبريل.

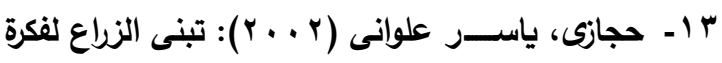

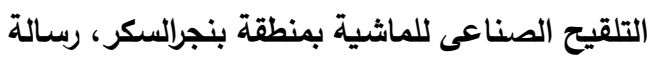
ماجستير، كلية الزراعة، جامعة الإسكندرية.

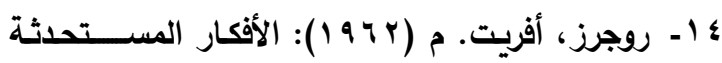

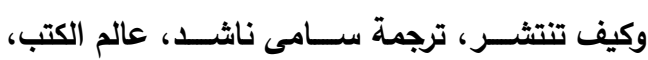
القاهرة.

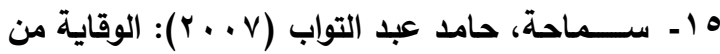

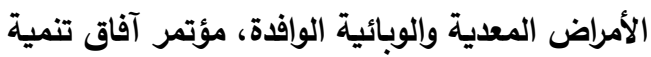
الثروة الحيوانية - المجترات، وزارة الزراعة وإستصلاح الأراضى، مركز البحوث الزراعية، الجيزة.
المعنية بسن القوانين والتشريعات اللزامة التى تمنع نقـل الأبقـار بين المحسافظـات أثنـاء فترات ظهور الإصـابة بمرض الجلد العقدى مع تفعيل دور الحجر البيطرى فى عدم إبــتيراد الأبقار الحاملة للإصـابة الجعابة بهذا المرض.

\section{المراجع العربية والأجنبية}

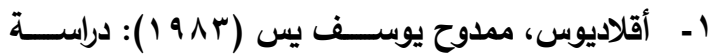
تحليليـة لبعض العوامل التى تؤثر على تبنى الزراع

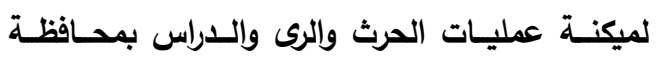

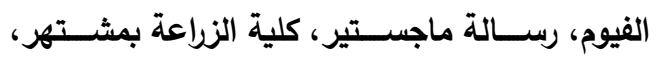

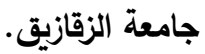
r- الإدارة الزراعية بمركزى المحلة الكبرى، وكفر الزيات

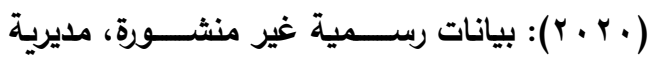
الزراعة بمحافظة الغربية.

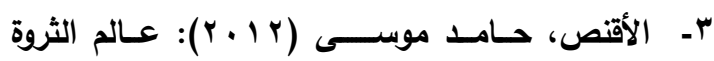
الحيوانية والااجنة، مجلة علمية شرق أوسطية، العدد

$$
\text { الثانى، يونيه. }
$$

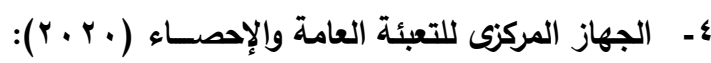
كتاب الإحصاء السنوى، يناير، القاهرة.

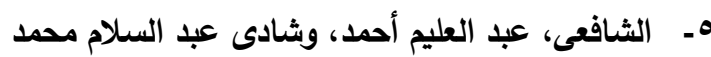

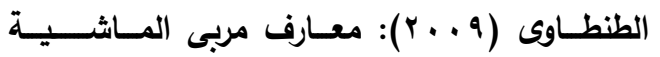

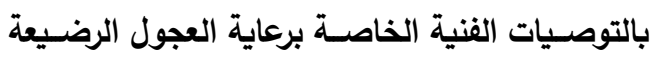

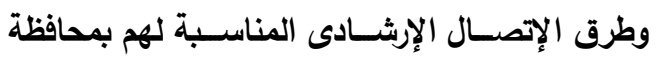

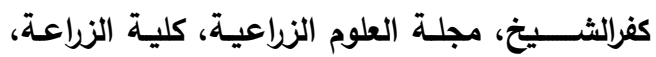
جامعة المنصورة، مجلد ؛ ب ، العدد (• (1)، إكتوبر.

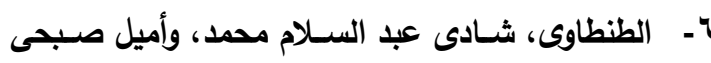

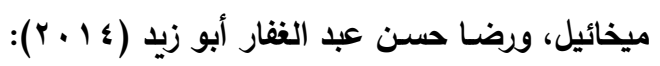
المتغيرات المؤثرة على تبنى مربى الماشية للتوصيات

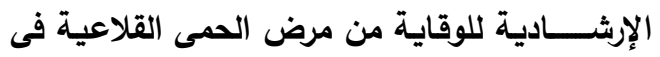
محافظة كفر الثـيخ، مجلة الجمعية العلمية للإرشساد الزراعى، المجلد الثامن عشر، العدد الرابع. -V

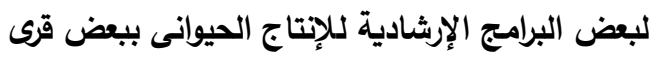


Sh. A. M. El Tantawy, et al.,

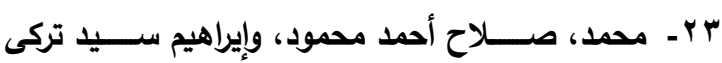

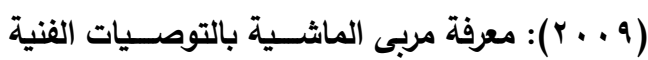

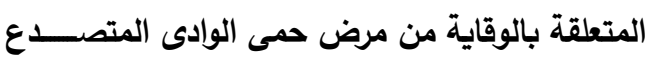

ببعض قرى مركز التل الكبير بمحافظة الإســــاعلية،

المجلة المصـرية للعلوم التطبيقية بالثــرقية، مجلد

$$
\text { ؟ Y، عدد (V)، بوليه. }
$$

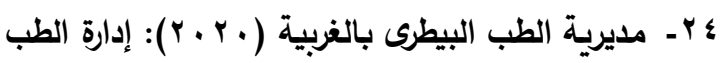

$$
\text { الوقائى، بيانات رسمية غير منشورة. }
$$

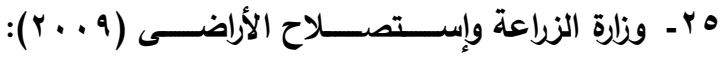

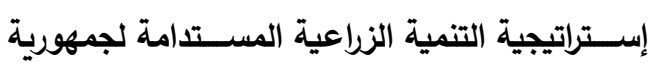

مصر العربية حتى عام • ب . r، الجيزة.

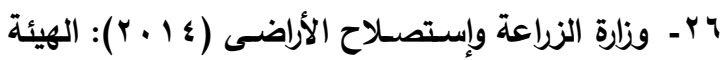

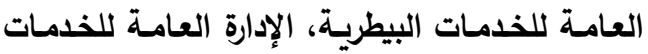

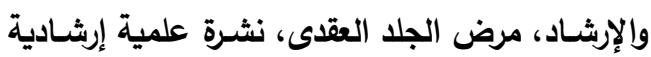

$$
\text { تصدر عن الإرشاد البيطرى، الجيزة. }
$$

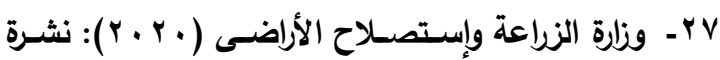

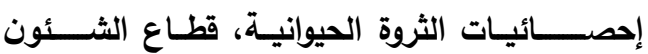

$$
\text { الإقتصادية، يناير، الجيزة . }
$$

28- Krejcei, R.V. and D.W. Morgan (1970): Determining sample size for research activities, educational and psychological Measure Carolina U.S.A, MENT.

29-Rogers, M. Evertt (1995): Diffusion of Innovation, third edition, the free press collier Macmillan publishers, London.
17 - شـلبى، أسـماء حامد على (ع . . ب): الآثار التعليمية

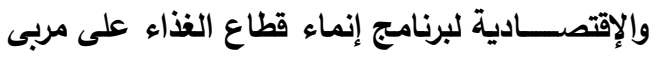

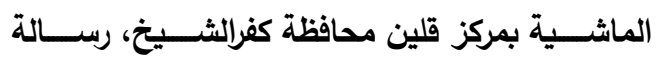
دكتوراه، كلية الزراعة بكفرالثيخ، جامعة طنطا.

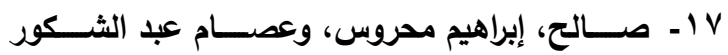

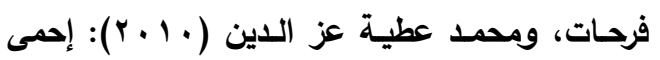
حيواناتك من الجلد العقدى.

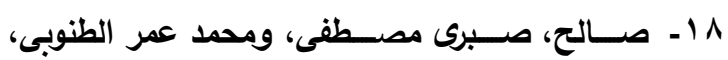

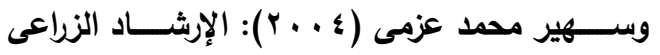

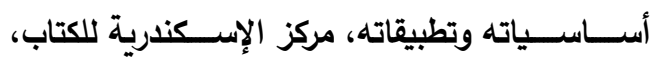

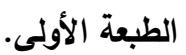

19 - صـــقر، زغلول محمد على، وعصــــام عبد اللطيف الاول.

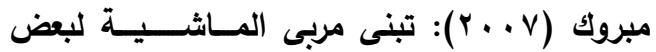

توصـــيات الرعايـة البيطريـة ببعض قرى محسافظة

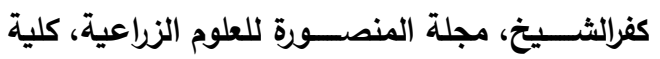

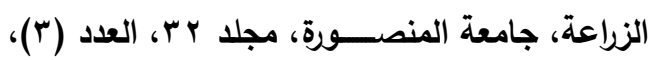

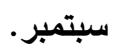

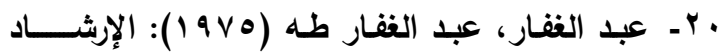

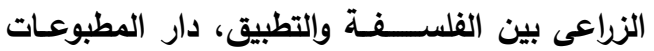

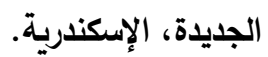

ا Y - عبد المقصـــود، بهجت محمد (9^1 ()): الإرشــــاد

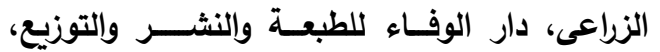

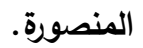

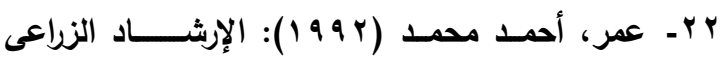

المعاصر، مصر للذدمات العلمية، القاهرة. 


\title{
COW BREEDERS' ADOPTION OF EXTENSION RECOMMENDATIONS TO PREVENTION OF LUMPY SKIN DISEASE IN SOME VILLAGES OF GHARBIA GOVERNORATE
}

\author{
Sh. A. M. El Tantawy, A. M. A. Amer and Walaa I. I. El-Moghazy \\ Agricultural Extension and Rural Development Research Institute - \\ Agricultural Research Center
}

\begin{abstract}
This research aimed to identify the level of cow breeders' adoption of respondents to prevention of lumpy skin disease, their correct application rate for each of these recommendations, and the sources of information which the respondents derive their knowledge about these recommendations, and determine the correlation between their degree of adoption of these recommendations and the studied independent variables, and determine the percentage of the contribution of each variable of the studied independent variables with significant correlation in the interpretation of the total variation occurred in the degree of adoption of cow breeders respondents of extension recommendations to prevention of lumpy skin disease, and finally identify the obstacles which face respondents to adopt these recommendations from their point of view.
\end{abstract}

This research was conducted in the two districts of Al-Mahalla Al-Kubra and Kafr Al-Zayyat in Gharbia Governorate, which sorted in the first rank according to the rates of contracted lumpy skin disease, and by the same criterion, the two largest villages from each center were chosen as villages: Mahlet-hassen and Damro from Al-Mahalla Al-Kubra district and Delbshan and Meshla from Kafr Al-Zayyat district. a regular random sample of 234 respondents was chosen from them according to the Krejcie \& Morgan equation representing 39\% of the total comprehensive research, which amounted to 600 cow breeders who possess three heads of cows or more in the four selected villages. The research data was collected by the questionnaire using the personal interview from the respondents of the research during February 2020 after initially testing them and making the necessary adjustments, then using the tabular presentation with frequencies, percentages, mean, standard deviation, Pearson's simple correlation coefficient, and the step-wise multiple regression in the statistical analysis data and display results.

The most important results of the research were the following:

1- 53\% of cow breeders respondents were subject to a low level of adoption of extension recommendations to prevention of lumpy skin disease.

2- It was found that the least extension recommendations to prevention of lumpy skin disease according to the correct rate of application were: immediate reporting of preventive medicine when the disease appears in cows (47.9\%), disposal of dead cows by burial and burning (45.7\%), and immunization of healthy old cows which have no disease symptoms or a high temperature (44.4\%), and immunization the old cows periodically every year (42.3\%).

3- The most important sources of information from which cow breeders derive their knowledge to prevention of lumpy skin disease were: the senior livestock breeders in the village who occupied the first rank, while the family and neighbors, and personal experience occupied advanced positions and following them. 
Sh. A. M. El Tantawy, et al.,

4- there are six independents variables combined together explain $49.1 \%$ of the total variation that occurred in the degree of cow breeders' adoption of extension recommendations to prevention of lumpy skin disease, namely: the degree of education of the respondent (19\%), farm animal tenure (10.5\%), The degree of knowledge of symptoms of lumpy skin disease (7,2\%), experience in animal husbandry (5\%), the degree of availability of veterinary services to prevention of lumpy skin disease $(4,6 \%)$, and the degree of veterinary contact $(2,8 \%)$.

5- cow breeders respondents pointed out to twelve obstacles face them when adopting extension recommendations to prevention of lumpy skin disease from their point of view as following: lack of vaccines in the veterinary unit in timely $(94,02 \%)$, increased vaccine prices in the veterinary offices $(89,84 \%)$, the lack of veterinary medicines at affordable prices in the veterinary unit to treat the disease (84.62\%). the lack of veterinary awareness among breeders (78,49\%).

Key words: Adoption, recommendations to prevention, lumpy skin disease

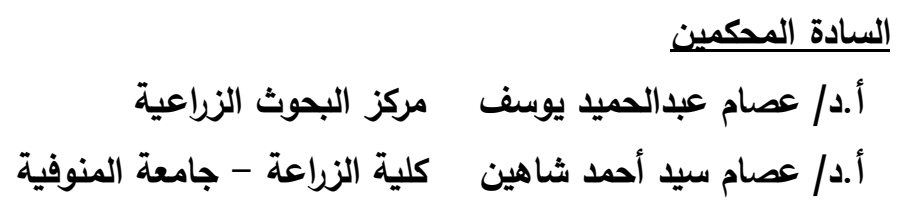

